\title{
Silica fluxes in the northeast Atlantic frontal zone of Mode Water formation $\left(38^{\circ}-45^{\circ} \mathrm{N}, 16^{\circ}-22^{\circ} \mathrm{W}\right)$ in $2001-2002$
}

\author{
Julie Mosseri, Bernard Quéguiner, and Peggy Rimmelin \\ Laboratoire d'Océanographie et de Biogéochimie, UMR 6535, Centre National de Recherche Scientifique/Université de la \\ Méditerranée, OSU/Centre d'Océanologie de Marseille, Parc Scientifique et Technologique de Luminy, Marseille, France
}

Nathalie Leblond and Cécile Guieu

Laboratoire d'Océanographie de Villefranche, Université Pierre et Marie Curie, Villefranche-sur-mer, France

Centre National de Recherche Scientifique/Institut National des Sciences de l'Univers, Villefranche-sur-mer, France

Received 15 July 2004; revised 24 March 2005; accepted 26 April 2005; published 30 June 2005.

[1] The biogenic (BSi) and lithogenic (LSi) silica export fluxes were investigated in the northeast Atlantic $\left(38^{\circ}-45^{\circ} \mathrm{N}, 16^{\circ}-22^{\circ} \mathrm{W}\right)$ as part of the Programme Océan Multidisciplinaire Méso Echelle (POMME) program in 2001-2002. They were measured at four stations located on both sides of a frontal zone $\left(40^{\circ}-42^{\circ} \mathrm{N}\right)$ by means of permanent moorings of sediment traps deployed at 400 and $1000 \mathrm{~m}$ depth. Averaged over the area, the annual BSi fluxes (corrected from ${ }^{230} \mathrm{Th}$ trapping efficiencies) ranged between $0.240 \mathrm{mmol} \mathrm{m}^{-2} \mathrm{~d}^{-1}$ at $400 \mathrm{~m}$ to $0.316 \mathrm{mmol} \mathrm{m}^{-2} \mathrm{~d}^{-1}$ at $1000 \mathrm{~m}$. The bulk annual BSi fluxes are comparable to bulk BSi export fluxes recorded for oligotrophic areas. The annual export flux of LSi (range $0.029 \mathrm{mmol} \mathrm{m}^{-2} \mathrm{~d}^{-1}$ at $400 \mathrm{~m}$ to $0.054 \mathrm{mmol} \mathrm{m}^{-2} \mathrm{~d}^{-1}$ at $1000 \mathrm{~m}$ ) was lower than BSi and accounted for $10 \%$ of the total silica export flux. Results show a strong coupling between the two siliceous particulate fractions, which is interpreted as reflecting LSi scavenging by BSi and limitation of BSi production in surface water by lithogenic (trace metals) inputs. BSi export was maximum at the beginning of the productive season during the spring bloom. However, annual BSi export fluxes in 2001 were quite higher at $400 \mathrm{~m}$ in the southern area (e.g., $0.249-0.288$ at the southeast station versus $0.211 \mathrm{mmol} \mathrm{BSi} \mathrm{m}{ }^{-2} \mathrm{~d}^{-1}$ at the northeast station) contradictory to the classical south-north surface production increase. We suggest an advective lateral transport within the upper $400 \mathrm{~m}$ of siliceous particles from the northern, more productive area to the southern region.

Citation: Mosseri, J., B. Quéguiner, P. Rimmelin, N. Leblond, and C. Guieu (2005), Silica fluxes in the northeast Atlantic frontal zone of Mode Water formation $\left(38^{\circ}-45^{\circ} \mathrm{N}, 16^{\circ}-22^{\circ} \mathrm{W}\right)$ in $2001-2002, J$. Geophys. Res., 110, C07S19, doi:10.1029/2004JC002615.

\section{Introduction}

[2] The ocean plays a key role in the regulation of global atmospheric $\mathrm{CO}_{2}$ by sequestering it and consequently mitigating the impact of anthropogenic $\mathrm{CO}_{2}$ emissions. The uptake of $\mathrm{CO}_{2}$ by the ocean is due to two mechanisms: the physical exchange of $\mathrm{CO}_{2}$ at the sea surface coupled to ocean circulation processes (the solubility carbon pump) [Broecker, 1991] and the photosynthetic fixation of $\mathrm{CO}_{2}$ by phytoplankton and subsequent gravitational transport of particulate organic and biomineral matter to the deep ocean and ultimately to the sediments (the biological carbon pump) [Westbroek et al., 1993].

[3] Major organic carbon fluxes to the sediments are frequently associated with diatom blooms [Buesseler, 1998]. This largest size class of phytoplankton accounts for more than $40 \%$ of the global oceanic primary production

Copyright 2005 by the American Geophysical Union. 0148-0227/05/2004JC002615 (from $25 \%$ in open ocean oligotrophic areas up to $75 \%$ on average in eutrophic coastal areas) [Nelson et al., 1995] and is a major vector for rapid organic matter export to the deep sea [Smetacek, 1985; Newton et al., 1994]. Diatoms being characterized by their ability to produce siliceous walls, the marine silica cycle is intimately coupled to the global carbon cycle.

[4] The North Atlantic Ocean has been proposed as a major sink for atmospheric $\mathrm{CO}_{2}$ [Sarmiento et al., 1995] particularly around the end of winter [Takahashi et al., 1995] and in spring [Rios et al., 1995] through the combined actions of the thermohaline circulation and the biological pump. Intense spring blooms have been observed at the time of water mass stratification [Esaias et al., 1986]. The spring bloom, usually initially dominated by diatoms [Lochte et al., 1993; Boyd and Newton, 1995], is likely to export high amounts of organic carbon to the deep ocean [Buesseler, 1998]. An essential element to the North Atlantic circulation and its interaction with the atmosphere is the Mode Water formation at the time 




Figure 1. Location of the (a) Programme Océan Multidisciplinaire Méso Echelle (POMME) study area and of the (b) four mooring stations. The dashed line indicates the approximate location of the frontal zone. At every station, two sediment traps have been deployed at 400 and $1000 \mathrm{~m}$ depth.

of deep winter convection and its subduction under warmer waters during the spring warming. A strong meridional gradient in the mixed layer depth coinciding with an hydrological front defined as the "line of zero buoyancy flux" by Paillet and Arhan [1996] is related to this subduction process. This winter mixed layer depth discontinuity zone divides the North Atlantic basin into two regions: a rather productive one to the north associated with deep winter mixed layers (reaching about $500 \mathrm{~m}$ ) and a more oligotrophic one to the south in relation with shallower winter mixed layers $(100-150 \mathrm{~m})$ [Wroblewski et al., 1988]. Consequently, as mentioned by Maixandeau et al. [2005] the study area is located at the transition between the North Atlantic Drift and the North Atlantic Subtropical provinces defined by Longhurst et al. [1995].

[5] In 2001, the Northeast Atlantic was investigated during the multidisciplinary French oceanographic Programme Océan Multidisciplinaire Méso Echelle (POMME) [Mémery et al., 2005]. The main goal of POMME was to understand the formation and subduction mechanisms of Subpolar Mode Water [McCartney and Talley, 1982] and the associated processes of carbon export.

[6] As a proxy, the particulate silica presents a particular significance for the organic carbon export: biogenic silica (BSi) is a tracer of diatoms, the main actors of the biological pump [Buesseler, 1998] and lithogenic silica (LSi) represents a tracer of lithogenic supplies which can influence primary productivity (e.g., by trace metal inputs) [Claustre et al., 2002].

[7] This study aimed at investigating the biological pump features in the Northeast Atlantic by examining the downward BSi and LSi fluxes using data collected from February 2001 to June 2002 through sediment trap deployments at four different stations located on both sides of a frontal zone coinciding with the line of subduction described by Paillet and Arhan [1996] in the POMME study area. The main objective of this paper is to describe the magnitude and composition of biogenic and lithogenic silica fluxes with special attention to the temporal (both seasonal and interannual) as well as to the spatial variability (variability with depth and between different stations) in order to derive an annual estimate of these fluxes. Also, the link between these export fluxes and surface productivity data will be examined.

\section{Material and Methods}

\subsection{Sampling Strategy}

[8] The study was carried out during 2001-2002 in the northeast Atlantic $\left(38^{\circ}-45^{\circ} \mathrm{N}, 16^{\circ}-22^{\circ} \mathrm{W}\right)$ (Figure 1a) on board the Navire Océanographique R/V L'Atalante, the R/V Thalassa (IFREMER), and the $\mathrm{R} / \mathrm{V}$ d'Entrecasteaux (SHOM). Particle fluxes were investigated at four mooring stations (northeast, northwest, southeast, and southwest) from February 2001 to June 2002. As the area was divided by a frontal zone around $42^{\circ} \mathrm{N}$ [Paillet and Arhan, 1996], two of the stations were positioned in the northern part of the domain and the two others in the southern part (Figure 1b). At each station, the mooring was supplied with two sediment traps (conical PPS5, 24 cup collector, $1 \mathrm{~m}^{2}$ sampling area) which were deployed at 400 and $1000 \mathrm{~m}$ depth. Two deployments of sediment traps were performed, with the exception of the southwest station where there was only one deployment; the first trap deployment was made from February to August 2001 and the second one from September 2001 to June 2002. The two successive deployments enabled particle flux investigation for more than 1 year including two spring bloom periods. Each sampling cup collected material during 8 day intervals for the first trap deployment; the sampling 
temporal resolution was decreased to 12 day intervals for the second trap deployment. Table 1 summarizes the characteristics of the sediment trap deployments. Further presentation of the POMME program can be found at http://www.lodyc. jussieu.fr/POMME.

\subsection{Chemical Analysis}

\subsubsection{Analytical Procedure}

[9] Sediment trap samples were freeze dried after recovery of the moorings. Measurements of biogenic silica (BSi) and lithogenic silica (LSi) were made on the same samples using a NaOH/HF digestion modified from Brzezinski and Nelson [1995], as detailed below. BSi was initially dissolved by $\mathrm{NaOH}$ digestion [Paasche, 1973]. On the same sample LSi was then extracted by HF digestion. For the estimation of biogenic silica a mineral correction was made using a kinetic extraction procedure modified from DeMaster [1981].

[10] For each sample three replicates of $5 \mathrm{mg}$ dry material were weighted and placed into polypropylene cylindrical centrifuge tubes. A first treatment by addition of $1 \mathrm{~mL}$ of $10 \% \mathrm{H}_{2} \mathrm{O}_{2}$ solution was performed to eliminate organic matter and to expose opal surfaces to dissolution. The samples were homogenized by a Vortex ${ }^{\circledR}$ mixer and sonicated for $30 \mathrm{~min}$. The samples were then dried for $24 \mathrm{~h}$ at $60^{\circ} \mathrm{C}$. Alkaline BSi extraction was made using the DeMaster [1981] technique which is based on the difference between rapid dissolution of $\mathrm{BSi}$ and slower dissolution of LSi (see Figure 2). An aliquot of $40 \mathrm{~mL} 0.2 \mathrm{~N}$ $\mathrm{NaOH}(\mathrm{pH}=13.1)$ was added to the sample prior to placing the centrifuge tubes (covered by plastic caps with pin holes to allow gas expansion) in a $95^{\circ} \mathrm{C}$ water bath. For each set of samples six blanks were made. Next $200 \mu \mathrm{L}$ aliquots were removed from the extraction solutions after 2 and 4 hours then placed into polyethylene scintillation vials which were completed to $10 \mathrm{~mL}$ and analyzed for dissolved silicic acid using the acid-molybdate spectrophotometric method [Strickland and Parsons, 1972]. The digestion time was chosen after preliminary tests insuring that BSi was completely dissolved after 2 hours extraction. The 4 hour digestion time was chosen in order to estimate a possible interference with LSi extraction which happened to be weak for all the sets of samples from our study area. The mass of silica extracted was plotted versus time. When the amount of silica extracted after 4 hour digestion time was higher than the one extracted after 2 hours, a mineral correction procedure was applied; another extraction was carried out on the same sample with a broader range of digestion times to estimate graphically the BSi content of the sample as on the DeMaster [1981] classical procedure (Figure 2). Digestion times of 30,60,90, 120, 180 and $240 \mathrm{~min}$ were chosen for these detailed kinetic extractions. This mineral correction proved to be necessary for 33 among 311 samples and provided reassessments of BSi fluxes ranging from 0 to $25 \%$ of initial estimate. Such corrections were shown to be of minor importance as highest BSi flux reassessment percentages corresponded to very low BSi fluxes (Figure 3).

[11] After BSi extraction, samples were run for LSi extraction following a procedure modified from Brzezinski and Nelson [1995]. Volumes of $13 \mathrm{~mL}$ of supernatant were 


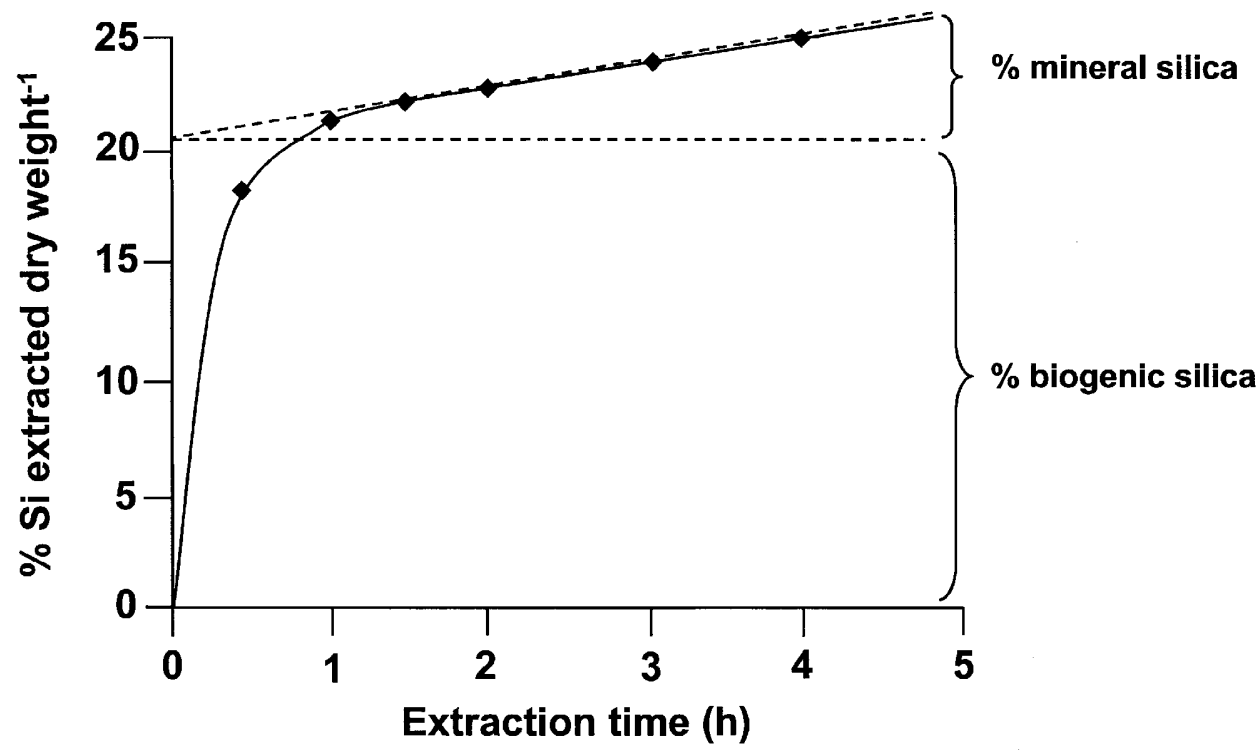

Figure 2. Kinetics of silica extraction versus time. The first part of the curve mainly corresponds to rapid BSi dissolution, whereas the second, linear one corresponds to slower LSi dissolution. The biogenic silica content of the sample is estimated by linear extrapolation at time zero intercept.

withdrawn and replaced by $13 \mathrm{~mL}$ of Milli-Q water to rinse the remaining particulate material. The tubes were then centrifuged for $10 \mathrm{~min}(1347 \times \mathrm{g})$ and $13 \mathrm{~mL}$ of supernatant were withdrawn again. Samples were then dried for $48 \mathrm{~h}$ at $60^{\circ} \mathrm{C}$. After drying, $0.2 \mathrm{~mL} 2.9 \mathrm{~N} \mathrm{HF}$ was added. After 48 hours LSi dissolution at room temperature $19.6 \mathrm{~mL}$ saturated $\mathrm{H}_{3} \mathrm{BO}_{4}\left(60 \mathrm{~g} \mathrm{~L}^{-1}\right)$ were added in order to neutralize $\mathrm{F}^{-}$ions which prevent from silicomolybdate complex formation. Next $5 \mathrm{~mL}$ aliquots were then placed into scintillation vials which were completed with $5 \mathrm{~mL}$ of Milli-Q water and analyzed for dissolved silicic acid.

[12] For the two digestion steps the resulting solutions were analyzed for dissolved silicic acid by the acidmolybdate method of Strickland and Parsons [1972] modified by Nelson et al. [1989]. Samples were run on a CECIL (CE 1011) spectrophotometer with a detection limit $<100 \mathrm{nM}$.

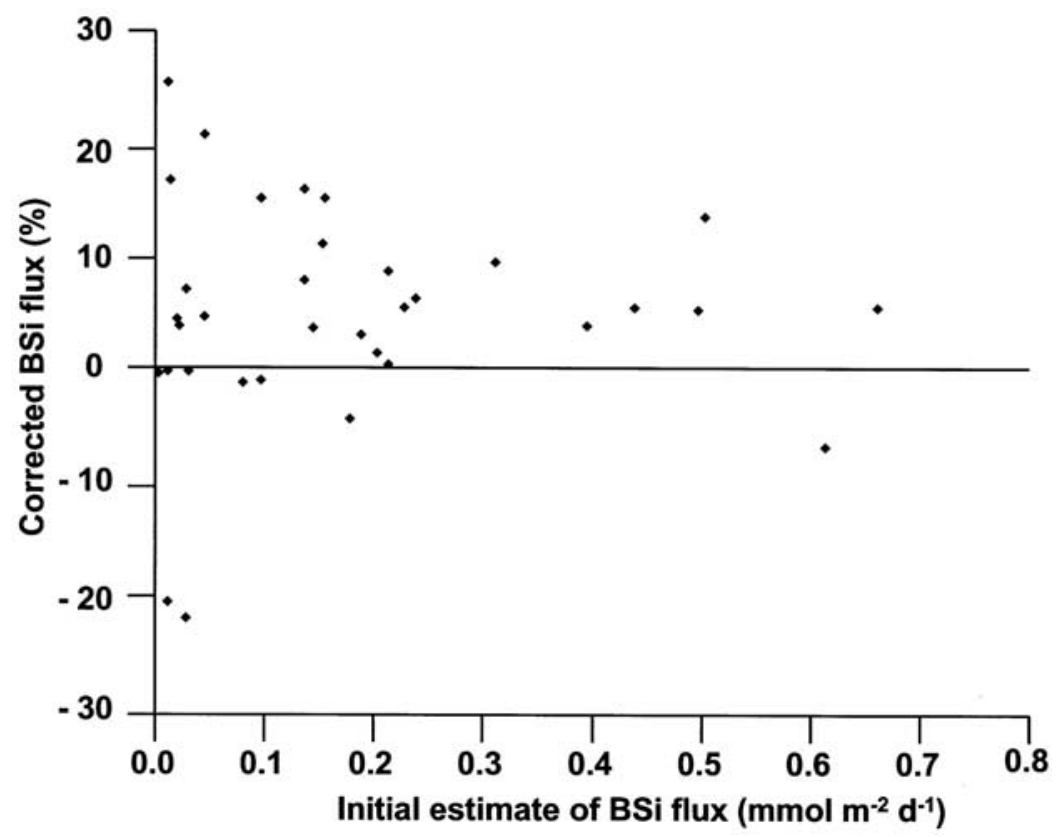

Figure 3. Percentage of reassessment of BSi fluxes from mineral correction against estimates of BSi fluxes $\left(\mathrm{mmol} \mathrm{m} \mathrm{m}^{-2} \mathrm{~d}^{-1}\right)$ without mineral correction. 
Table 2. Estimates of Annual Average Mass, BSi, and LSi Fluxes (Data Corrected From ${ }^{230}$ Th Trapping Efficiency) ${ }^{\mathrm{a}}$

\begin{tabular}{|c|c|c|c|c|c|c|c|c|}
\hline & \multicolumn{2}{|c|}{ Northeast Station } & \multicolumn{2}{|c|}{ Southeast Station } & \multicolumn{2}{|c|}{ Northwest Station } & \multicolumn{2}{|c|}{ Southwest Station } \\
\hline & $400 \mathrm{~m}$ & $1000 \mathrm{~m}$ & $400 \mathrm{~m}$ & $1000 \mathrm{~m}$ & $400 \mathrm{~m}$ & $1000 \mathrm{~m}$ & $400 \mathrm{~m}$ & $1000 \mathrm{~m}$ \\
\hline Annual average mass flux, $\mathrm{mg} \mathrm{m}^{-2} \mathrm{~d}^{-1}$ & 182.2 & 151.5 & $106.8-120.5$ & 122.5 & n.d. & 108.8 & n.d. & n.d. \\
\hline Annual average BSi flux, $\mathrm{mmol} \mathrm{m}^{-2} \mathrm{~d}^{-1}$ & 0.211 & 0.347 & $0.249-0.288$ & 0.265 & n.d. & 0.336 & n.d. & n.d. \\
\hline Annual average LSi flux, $\mathrm{mmol} \mathrm{m}^{-2} \mathrm{~d}^{-1}$ & 0.022 & 0.048 & $0.034-0.039$ & 0.059 & n.d. & 0.055 & n.d. & n.d. \\
\hline
\end{tabular}

${ }^{\text {a } T h e ~ a n n u a l ~ a v e r a g e ~ f l u x ~ i s ~ c a l c u l a t e d ~ f r o m ~ F e b r u a r y ~ 2001-2002 ; ~ m i s s i n g ~ d a t a ~ d u r i n g ~ t h e ~} 15$ day gap between the two deployments are replaced by the average of the two available adjacent fluxes (n.d., not determined).

\subsubsection{Calculations}

[13] For each replicate, the mass (in grams) of silica collected by a cup collector was calculated as follows:

$$
m=\frac{A * \times s \times F \times V \times 28.09 \times \text { grams in the cup collector }}{\text { grams in the replicate }},
$$

where

$A^{*}$ absorbance corrected from the average absorbance of the blanks;

$s$ slope of the linear regression between blank corrected absorbance and dissolved silicic acid concentration of the standards (mol L ${ }^{-1}$ absorbance unit $\left.^{-1}\right)$;

$F$ dilution factor;

$V$ extraction volume (L);

28.09 silicon atomic weight $\left(\mathrm{g} \mathrm{mol}^{-1}\right)$.

[14] For each sample, the average mass of silica, the standard deviation, and the precision (\%) were estimated from three replicates. For BSi extractions we compared the average mass of silica extracted after 2 and 4 hours digestion time. In the absence of any consistent increasing trend in silica extracted with time, we calculated the $\mathrm{BSi}$ concentration as the average of the three replicate results obtained after 2 hour digestion. On the contrary, when the amount of silica extracted increased with time, then the mass of silica was determined graphically as in Figure 2 from a detailed kinetic extraction as mentioned above.

[15] BSi or LSi fluxes (mol $\mathrm{Si} \mathrm{m}^{-2} \mathrm{~d}^{-1}$ ) were then calculated as follows:

$$
F=\frac{m}{\text { days in collection duration } \times 28.09} .
$$

[16] Also, when it was necessary to convert biogenic silica concentrations ( $\mathrm{mol} \mathrm{Si}$ ) to particulate biogenic silica fluxes $\left(\mathrm{mg} \mathrm{SiO}_{2}, \mathrm{nH}_{2} \mathrm{O} \mathrm{m} \mathrm{m}^{-2} \mathrm{~d}^{-1}\right.$ ), we assumed that biogenic silica contains on average $10 \%$ water by weight [Mortlock and Froelich, 1989]. The average precisions were respectively $16 \%$ and $24 \%$ for BSi flux and LSi flux measurements.

[17] During POMME mooring deployments, from ${ }^{230} \mathrm{Th}$ analysis, trapping efficiencies between February 2001 and February 2002 were estimated to be (1) at $400 \mathrm{~m}: 18.5 \%$ for the northeast station trap, $28.5 \pm 6.5 \%$ for the northwest station trap, $55 \pm 4 \%$ for the southeast station trap, $43.5 \pm$ $14.5 \%$ for the southwest station trap and (2) at $1000 \mathrm{~m}$ : $32 \%$ for the northeast station trap, 33\% for the northwest station trap, 34\% for the southeast station trap and $27.5 \pm$ $9.5 \%$ for the southwest station trap. However, there were no
${ }^{230} \mathrm{Th}$ measurements after February 2002 [Guieu et al., 2005]. The trapping efficiencies are in accordance with published data that indicate relatively low numbers $(40 \%$ on average) for sediment traps deployed above 1000-1500 m depth where undertrapping biases are generally reported [Scholten et al., 2001; Yu et al., 2001; Usbeck et al., 2003]. The ${ }^{230}$ Th method theoretically can be used to apply an annual correction to particle fluxes for trapping efficiency. However it does not enable to take into account of the seasonal variability of the nature of aggregate particulate material and of the related scavenging intensity. For these reasons we chose to use our uncorrected flux data for visualization of the export flux seasonal evolution (i.e., the figuration of the BSi and LSi export fluxes obtained cup by cup) and discussion about these export fluxes on a seasonal basis. A part of the discussion is also based on values corrected from ${ }^{230} \mathrm{Th}$ calibration. Indeed, this allows a better comparison of the seasonal patterns between sites. It is also important to take into account these corrections in the calculation of the annual silica export.

\section{Results}

\subsection{Mass Flux}

[18] Mass fluxes (data not corrected from ${ }^{230} \mathrm{Th}$ trap calibration) were at their highest in spring $2001(\sim 100-$ $\left.350 \mathrm{mg} \mathrm{m}^{-2} \mathrm{~d}^{-1}\right)$, decreased in summer and were low in autumn and winter $\left(\sim 1-40 \mathrm{mg} \mathrm{m}^{-2} \mathrm{~d}^{-1}\right)$ before increasing again in spring 2002 without reaching values as high as in 2001 (see bulk data by Guieu et al. [2005, Figure 2]). The spring mass fluxes collected at the southeast and northwest stations were on average twofold higher in 2001 as compared to 2002 although year-to-year variability was less evident for the northeast station.

[19] In 2001, the $400 \mathrm{~m}$ depth spring mass fluxes and especially mass export peaks were highest at the southern stations. An inverse pattern characterized $1000 \mathrm{~m}$ depth spring mass fluxes although this was less obvious (see bulk data by Guieu et al. [2005, Figure 2]). However, these observations were to tone down by considering the collecting efficiencies of the traps. Indeed, if we applied the ${ }^{230} \mathrm{Th}$ annual correction factor to each flux of the year, then the north-south difference that was observed in the bulk data set (as described above) was strongly diminished and even slightly inverted. Looking at the ${ }^{230} \mathrm{Th}$ corrected data set, the $400 \mathrm{~m}$ depth spring mass fluxes seemed higher at the northern stations (see ${ }^{230}$ Th corrected data set by Guieu et al. [2005, Figure 2]). This was reflected on annual average mass fluxes (Table 2) which were mainly influenced by spring period. The annual average mass fluxes $\left({ }^{230} \mathrm{Th}\right.$ corrected data) at 400 and $1000 \mathrm{~m}$ were higher at the northeast station $\left(182 \mathrm{mg} \mathrm{m}^{-2} \mathrm{~d}^{-1}\right.$ at $400 \mathrm{~m}$ 
and $151 \mathrm{mg} \mathrm{m}^{-2} \mathrm{~d}^{-1}$ at $1000 \mathrm{~m}$ ) than at the southeast one $\left(107-120 \mathrm{mg} \mathrm{m}^{-2} \mathrm{~d}^{-1}\right.$ at $400 \mathrm{~m}$ and $122 \mathrm{mg} \mathrm{m}^{-2} \mathrm{~d}^{-1}$ at $1000 \mathrm{~m})$.

\subsection{BSi Flux}

[20] Following Honjo and Manganini [1993] we defined a particle bloom episode as a rapid and continuous increase in flux to a peak or peaks followed by a rapid and consistent decrease to the background flux. Figure 4 presents the BSi fluxes at $400 \mathrm{~m}$ and $1000 \mathrm{~m}$ depth at each station and the subsequent temporal division between bloom and non bloom episodes. Clearly BSi export fluxes were closely linked to the spring bloom sedimentation process as the major BSi particle bloom episodes were observed during springtime at every station. The BSi fluxes peaked between March and May depending on the station and passed through minima in autumn and winter mirroring the annual cycle of primary production in surface water [Leblanc et al., 2005].

[21] During the 2001 spring bloom, the $400 \mathrm{~m}$ depth BSi export peaks at the northern stations occurred in March. Estimates of these BSi export peaks were $0.300 \pm$ $0.010 \mathrm{mmol} \mathrm{m}^{-2} \mathrm{~d}^{-1}$ from 2 to 10 March at the northeast station and $0.472 \pm 0.019 \mathrm{mmol} \mathrm{m} \mathrm{m}^{-2} \mathrm{~d}^{-1}$ from 18 to 26 March at the northwest station. The BSi particle bloom episode lasted 72 days at the northeast station. Unfortunately, for the northwest station it was not possible to determine the end of the bloom period since the $400 \mathrm{~m}$ depth trap failed from May to August 2001. At the southern stations, the $400 \mathrm{~m}$ depth BSi export peaks were recorded later (end of March/beginning of April) as compared to the northern ones. However they were greater in magnitude: $0.946 \pm 0.066 \mathrm{mmol} \mathrm{m}^{-2} \mathrm{~d}^{-1}$ from 26 March to 3 April at the southeast station, and $0.718 \pm 0.029 \mathrm{mmol} \mathrm{m}^{-2} \mathrm{~d}^{-1}$ from 3 to 11 April at the southwest one. The BSi particle bloom episode lasted 176 days at the southeast station and 168 days at the southwest station, that is at least twofold longer than at the northeast station. However, these observations were still to modulate by considering the collecting efficiencies of the traps. If we correct each flux from ${ }^{230} \mathrm{Th}$ calibration for the period February 2001-2002, then the BSi export peak values were more similar between the four stations at $400 \mathrm{~m}\left(\sim 1.600-1.800 \mathrm{mmol} \mathrm{m}^{-2} \mathrm{~d}^{-1}\right)$ and did not present any south-north differing trend (1.622 and $1.775 \mathrm{mmol} \mathrm{m} \mathrm{m}^{-2}$ at the northeast and northwest station respectively versus 1.603 and $1.651 \mathrm{mmol} \mathrm{m}^{-2} \mathrm{~d}^{-1}$ at the southeast and southwest station respectively). At $1000 \mathrm{~m}$ the northern station major BSi export peaks (bulk data) were $0.543 \pm 0.006 \mathrm{mmol} \mathrm{m}^{-2} \mathrm{~d}^{-1}$ from 3 to 11 April at the northeast station and $0.641 \pm 0.025 \mathrm{mmol} \mathrm{m}^{-2} \mathrm{~d}^{-1}$ from 13 to 21 May at the northwest station. These $1000 \mathrm{~m}$ BSi export peaks were higher than the ones recorded at $400 \mathrm{~m}$ depth for these two northern stations. The particle bloom episode lasted 152 days at the northeast station and 176 days at the northwest one. At least for the northeast station, this $1000 \mathrm{~m}$ particle bloom duration was also longer than the duration of the particle bloom at the upper depth $(400 \mathrm{~m})$. At the southern stations, the $1000 \mathrm{~m} \mathrm{BSi}$ export peaks were recorded between 3 and 11 April for both southeast and southwest stations. The estimates were $0.569 \pm 0.038 \mathrm{mmol} \mathrm{m}^{-2} \mathrm{~d}^{-1}$ at the southeast station and $0.518 \pm 0.061 \mathrm{mmol} \mathrm{m}^{-2} \mathrm{~d}^{-1}$ at the southwest one. Unlike the spatial trends described above for the bulk BSi export at $400 \mathrm{~m}$ depth, the bulk BSi export peaks recorded at $1000 \mathrm{~m}$ at the southern stations were not higher than at the northern ones. Considering the standard deviations, the $1000 \mathrm{~m} \mathrm{BSi}$ export peaks were relatively homogeneous between the northern and the southern sites. Contrary to what was observed at $400 \mathrm{~m}$, the particle bloom episode duration at $1000 \mathrm{~m}$ was slightly shorter at the southeast and southwest stations (136 and 128 days, respectively) than at the northern stations. When fluxes were corrected from ${ }^{230} \mathrm{Th}$ calibration, we could note that the $1000 \mathrm{~m}$ BSi export peak values were more similar between the four stations $\left(\sim 1.650-1.900 \mathrm{mmol} \mathrm{m}^{-2} \mathrm{~d}^{-1}\right)$ and did not present any south-north differing trend (1.697 and $1.915 \mathrm{mmol} \mathrm{m}^{-2} \mathrm{~d}^{-1}$ at the northeast and northwest station respectively versus 1.674 and $1.884 \mathrm{mmol} \mathrm{m}^{-2} \mathrm{~d}^{-1}$ at the southeast and southwest station respectively). It is also interesting to note that when correction of trapping efficiency were applied, the $1000 \mathrm{~m} \mathrm{BSi}$ export peaks were higher than the ones recorded at $400 \mathrm{~m}$ for all the four stations. Also, during the $2001 \mathrm{BSi}$ particle bloom episodes, there were likely two sedimentation events separated by a gap around AprilMay. This feature was particularly clear at the southeast, southwest and northwest stations at $400 \mathrm{~m}$ as well as at $1000 \mathrm{~m}$.

[22] For the 2002 spring bloom, as the investigation period ended in June, the BSi particle bloom episode definition and especially its final limit was poorly constrained for some stations or some sampling depths. Figure 4 shows that the spring BSi particle bloom episode at the northeast station started from the end of March and lasted 84 days at $400 \mathrm{~m}$ as well as at $1000 \mathrm{~m}$ depth. The spring $\mathrm{BSi}$ particle bloom episode at the northwest station started from late February and from late April at 400 and $1000 \mathrm{~m}$ depth respectively and its termination was not clearly established. The spring BSi particle bloom episode at the southeast station started from March and lasted 96 days at $400 \mathrm{~m}$ while the data did not enable to constrain the end of the spring sedimentation at $1000 \mathrm{~m}$. With regards to flux intensities, the northeast station exhibited the highest spring bloom BSi particle flux both at 400 and $1000 \mathrm{~m}$. Estimates of BSi export peaks at $400 \mathrm{~m}$ in 2002 were $0.382 \pm 0.015 \mathrm{mmol} \mathrm{m}^{-2} \mathrm{~d}^{-1}$ (from 13 to 25 April) at the northeast station and $0.176 \pm$ $0.007 \mathrm{mmol} \mathrm{m}^{-2} \mathrm{~d}^{-1}$ (from 25 April to 7 May) at the northwest one. At the southern station southeast, it was $0.101 \pm 0.005 \mathrm{mmol} \mathrm{m}^{-2} \mathrm{~d}^{-1}$ (from 25 April to 7 May). At $1000 \mathrm{~m}$, BSi export peaks were $0.854 \pm 0.038$ (from 7 to 19 May) at the northeast station, and $0.202 \pm$ $0.011 \mathrm{mmol} \mathrm{m} \mathrm{m}^{-1}$ (from 7 to 19 May) at the northwest one. It was $0.255 \pm 0.009 \mathrm{mmol} \mathrm{m} \mathrm{m}^{-2} \mathrm{~d}^{-1}$ from 7 to 19 May at the southeast station. It is noteworthy that, contrary to spring 2001, during the spring 2002 particle bloom episode, maximum BSi fluxes were higher in the deeper trap at every station. As already mentioned, there were no trapping efficiency calibrations from ${ }^{230} \mathrm{Th}$ measurements for this period of the 2002 spring bloom.

[23] The annual BSi flux was calculated from late February 2001 to early February 2002. At $400 \mathrm{~m}$, the annual average BSi flux (corrected from ${ }^{230} \mathrm{Th}$ trapping efficiency) was quite higher at the southeast station $\left(0.249-0.288 \mathrm{mmol} \mathrm{m}^{-2} \mathrm{~d}^{-1}\right)$ than at the northeast one 

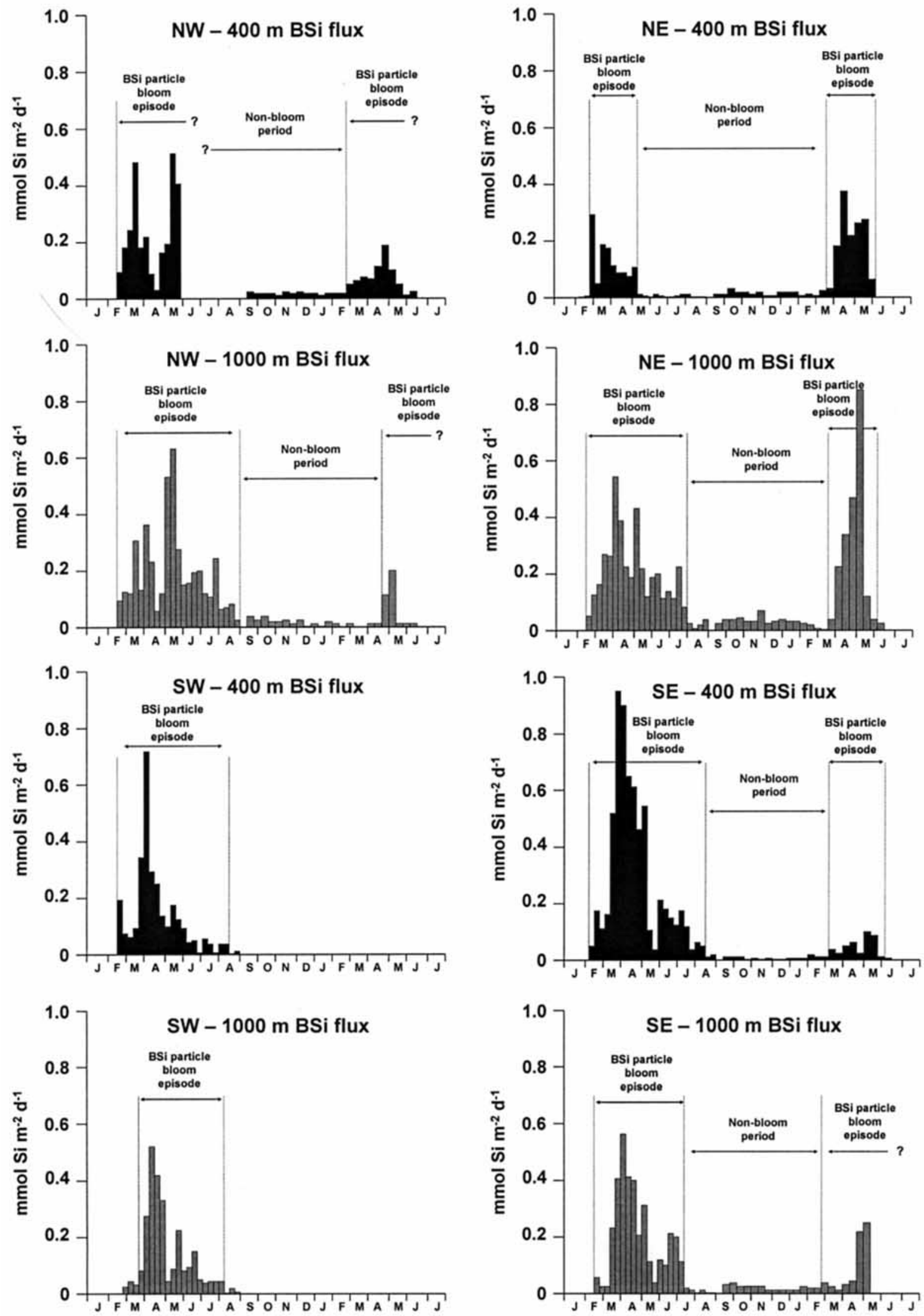

Figure 4. Seasonal evolution of BSi fluxes (bulk data) evidencing bloom and nonbloom BSi particle flux episodes. Question marks indicate when divisions between periods are not well constrained. 
$\left(0.211 \mathrm{mmol} \mathrm{m}^{-2} \mathrm{~d}^{-1}\right)$. At $1000 \mathrm{~m}$, the annual average BSi flux was higher at the northern stations (Table 2).

\subsection{LSi Flux}

[24] Figure 5 presents the LSi fluxes at 400 and $1000 \mathrm{~m}$ depth for each station (bulk data). The LSi fluxes closely resembled those of $\mathrm{BSi}$ : episodes of $\mathrm{LSi}$ export were encountered during springtime at the same time as BSi export events (i.e., during BSi particle bloom episodes) and LSi fluxes were low $\left(<0.020 \mathrm{mmol} \mathrm{m}^{-2} \mathrm{~d}^{-1}\right)$ during the rest of the year.

[25] During spring 2001, at $400 \mathrm{~m}$ depth bulk LSi fluxes were generally more important at the southern stations. However, the maximum LSi flux value $(0.125 \pm$ $0.005 \mathrm{mmol} \mathrm{m}^{-2} \mathrm{~d}^{-1}$ ) was recorded at the northwest station that presented a particularly high LSi export peak in March. For each of the $400 \mathrm{~m}$ traps, the LSi export peaks corresponded exactly in time with the $\mathrm{BSi}$ ones. Estimates of northern LSi export peaks at $400 \mathrm{~m}$ were $0.036 \pm$ $0.003 \mathrm{mmol} \mathrm{m}^{-2} \mathrm{~d}^{-1}$ at the northeast station from 2 to 10 March, and $0.125 \pm 0.005 \mathrm{mmol} \mathrm{m} \mathrm{m}^{-2} \mathrm{~d}^{-1}$ at the northwest station from 18 to 26 March. At the southern stations, they were $0.099 \pm 0.004 \mathrm{mmol} \mathrm{m}^{-2} \mathrm{~d}^{-1}$ at the southeast station from 26 March to 3 April, and $0.080 \pm$ $0.003 \mathrm{mmol} \mathrm{m} \mathrm{m}^{-2} \mathrm{~d}^{-1}$ at the southwest station from 3 to 11 April. The $400 \mathrm{~m}$ trap at the southwest station recorded an extra export peak $\left(0.070 \pm 0.001 \mathrm{mmol} \mathrm{m}^{-2} \mathrm{~d}^{-1}\right.$ from 22 February to 2 March) which had no counterpart in the BSi flux evolution. However, these observations were still to modulate by considering the collecting efficiencies of the traps. After correction from ${ }^{230} \mathrm{Th}$ calibration, the LSi export peak values were quite similar at the northeast, southeast, and southwest stations at $400 \mathrm{~m}(\sim 0.180-$ $\left.0.195 \mathrm{mmol} \mathrm{m}^{-2} \mathrm{~d}^{-1}\right)$. However, the northwest station at $400 \mathrm{~m}$, as already noticed for the bulk data set, presented a particularly high LSi export peak $\left(0.439 \mathrm{mmol} \mathrm{m}^{-2} \mathrm{~d}^{-1}\right)$. At $1000 \mathrm{~m}$, maximum bulk LSi fluxes were in the range $0.050-0.080 \mathrm{mmol} \mathrm{m}^{-2} \mathrm{~d}^{-1}$. Estimates of northern export peaks of LSi at $1000 \mathrm{~m}$ were $0.055 \pm 0.001 \mathrm{mmol} \mathrm{m}^{-2} \mathrm{~d}^{-1}$ (from 5 to 13 May) at the northeast station and $0.056 \pm$ $0.002 \mathrm{mmol} \mathrm{m}^{-2} \mathrm{~d}^{-1}$ (from 13 to 21 May) at the northwest station. They were $0.070 \pm 0.003$ and $0.081 \pm$ $0.007 \mathrm{mmol} \mathrm{m}^{-2} \mathrm{~d}^{-1}$ (from 3 to 11 April) at the southeast and southwest stations, respectively. After correction from ${ }^{230} \mathrm{Th}$ calibration, the LSi export peak values were higher at the southern stations $\left(0.206\right.$ and $0.291 \mathrm{mmol} \mathrm{m}^{-2} \mathrm{~d}^{-1}$ at the southeast and southwest stations, respectively) compared to the northern ones $\left(0.172\right.$ and $0.170 \mathrm{mmol} \mathrm{m}^{-2} \mathrm{~d}^{-1}$ at the northeast and northwest stations, respectively).

[26] During the spring 2002, the LSi fluxes were lower at the southeast and northwest stations but greater at the northeast one as compared to the spring 2001. Estimates of LSi export peaks at $400 \mathrm{~m}$ in 2002 were $0.070 \pm$ $0.019 \mathrm{mmol} \mathrm{m}^{-2} \mathrm{~d}^{-1}$ (from 13 to 25 April) at the northeast station and $0.017 \pm 0.001 \mathrm{mmol} \mathrm{m}^{-2} \mathrm{~d}^{-1}$ (from 25 April to 7 May) at the northwest station. At the southern station southeast, it was $0.037 \pm 0.003 \mathrm{mmol} \mathrm{m}^{-2} \mathrm{~d}^{-1}$ from 24 February to 8 March. At $1000 \mathrm{~m}$, the LSi export peaks were $0.088 \pm 0.007 \mathrm{mmol} \mathrm{m}^{-2} \mathrm{~d}^{-1}$ (from 7 to 19 May) at the northeast station, and $0.022 \pm 0.001 \mathrm{mmol} \mathrm{m}^{-2} \mathrm{~d}^{-1}$ (from 25 April to 7 May) at the northwest one. It was $0.044 \pm 0.004 \mathrm{mmol} \mathrm{m}^{-2} \mathrm{~d}^{-1}$ (from 7 to 19 May) at the southeast station. Like for BSi fluxes, the maximum spring 2002 LSi flux recorded was higher in the deeper trap at every station.

[27] As for the annual BSi flux pattern, after trapping efficiency correction the annual average LSi flux was quite higher at the southeast station $\left(0.034-0.039 \mathrm{mmol} \mathrm{m}^{-2} \mathrm{~d}^{-1}\right)$ than at the northeast station $\left(0.022 \mathrm{mmol} \mathrm{m} \mathrm{m}^{-2} \mathrm{~d}^{-1}\right)$ at $400 \mathrm{~m}$. At $1000 \mathrm{~m}$, the annual average LSi fluxes was of the same order of magnitude at the northern and southern stations and did not present any south-north spatial trend (Table 2).

\subsection{Contribution of the Siliceous Material to the Export Flux}

[28] The BSi fluxes were closely resembling total mass fluxes and almost every major mass flux peak had its counterpart as BSi (see bulk data by Guieu et al. [2005, Figure 2] and Figure 4). The BSi fluxes were plotted against mass fluxes (Figure 6a) for a 1 year sampling period (from February 2001 to February 2002). The slope of this regression indicated that $\mathrm{BSi}$ accounted for $18.3 \%$ of the annual mass flux.

[29] We investigated the contribution of BSi to mass flux in each cup collected in order to assess its seasonal variability (Figure 7). The percent contribution of BSi to mass flux was highest during springtime at every station; however the difference between the spring and the rest of the year seemed to be more pronounced at the southern southeast station. The BSi contribution increased by a threeto fivefold factor at the southeast station between the 2001 spring bloom BSi particle flux episode versus the nonbloom period (from 4 to $17 \%$ at $400 \mathrm{~m}$ and from 5 to $19 \%$ at $1000 \mathrm{~m}$ ). On the other hand at the northeast and northwest stations it increased only slightly during the 2001 spring bloom BSi particle flux episode as compared to the rest of the year (from 9 to $10 \%$ at $400 \mathrm{~m}$, and 11 to $17 \%$ at $1000 \mathrm{~m}$ at the northeast station and from 15 to $18 \%$ at the northwest station at $1000 \mathrm{~m}$ ). The contribution of the siliceous material to the mass export flux was very variable on year-to-year basis; results indicated a higher BSi contribution during the 2002 spring period $(21 \%$ at 400 and $1000 \mathrm{~m}$ ) as compared to the 2001 spring one $(10 \%$ at $400 \mathrm{~m}$ and $17 \%$ at $1000 \mathrm{~m})$ at the northeast station. On the opposite, the BSi contribution was higher during the 2001 spring period $(17 \%$ at $400 \mathrm{~m})$ than during the 2002 spring one $(7 \%$ at $400 \mathrm{~m})$ at the southeast station.

[30] The LSi fluxes were also correlated with mass fluxes and BSi fluxes from February 2001 to February 2002 (Figures $6 \mathrm{~b}$ and $6 \mathrm{c}$ ). LSi constituted a very little component of the global export flux as it accounted for only $0.9 \%$ of the annual mass flux and represented $10.2 \%$ of the total silica $(\mathrm{BSi}+\mathrm{LSi})$ fluxes.

\section{Discussion}

\subsection{Annual Silica Export}

[31] Averaged over the area, the annual BSi export fluxes range between $0.240 \mathrm{mmol} \mathrm{m} \mathrm{m}^{-2}$ at $400 \mathrm{~m}$ to $0.316 \mathrm{mmol} \mathrm{m}^{-2} \mathrm{~d}^{-1}$ at $1000 \mathrm{~m}$ (data corrected from ${ }^{230} \mathrm{Th}$ trapping efficiency). These comprise the annual BSi export fluxes (data corrected from ${ }^{230} \mathrm{Th}$ trapping efficiency, from Antia et al. [2001]) obtained at $1000 \mathrm{~m}$ at the northern 

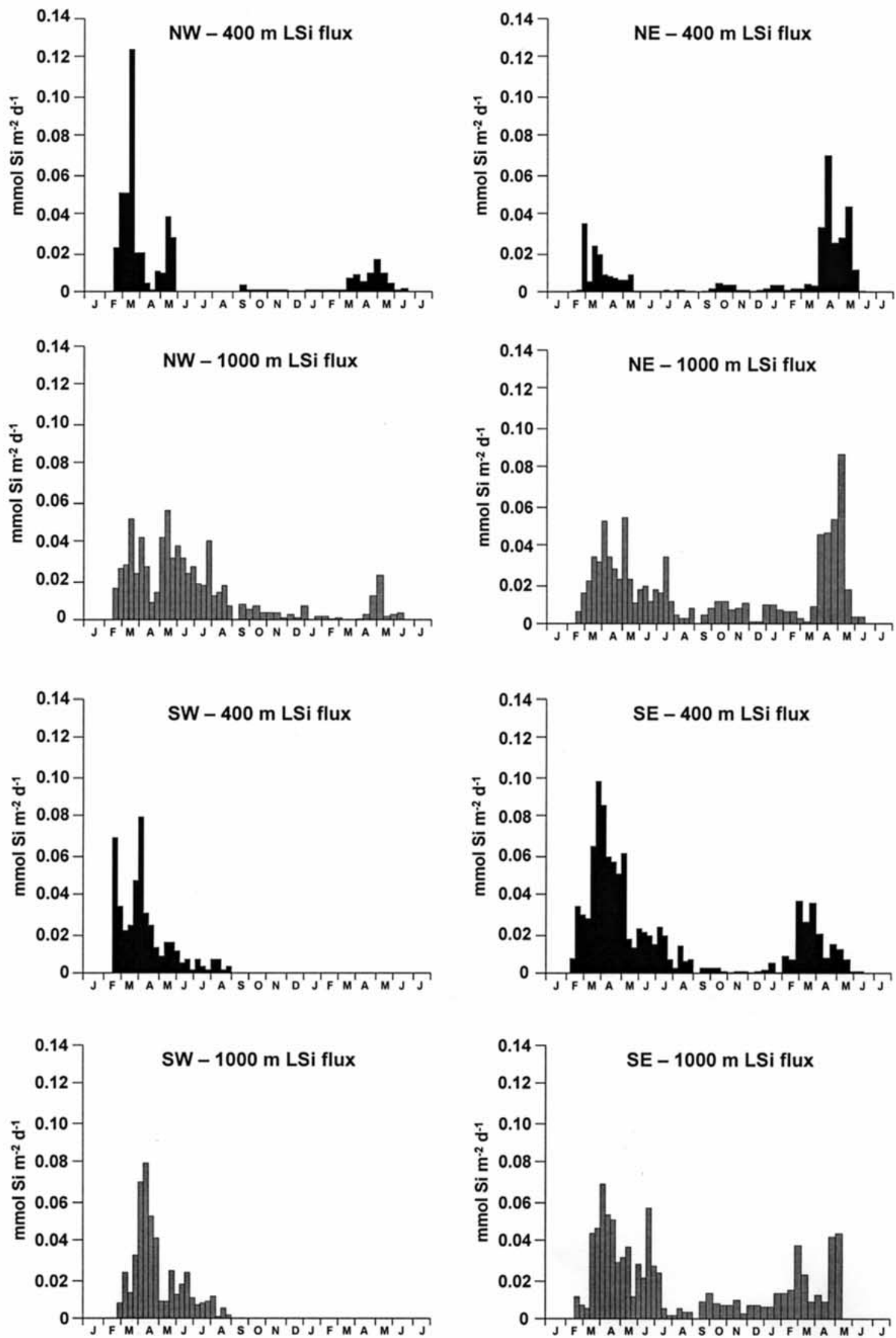

Figure 5. Seasonal evolution of LSi fluxes (bulk data). 
a

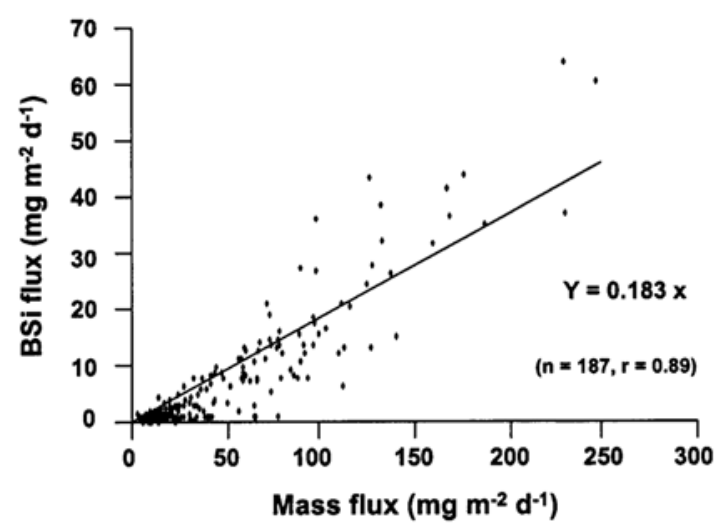

b

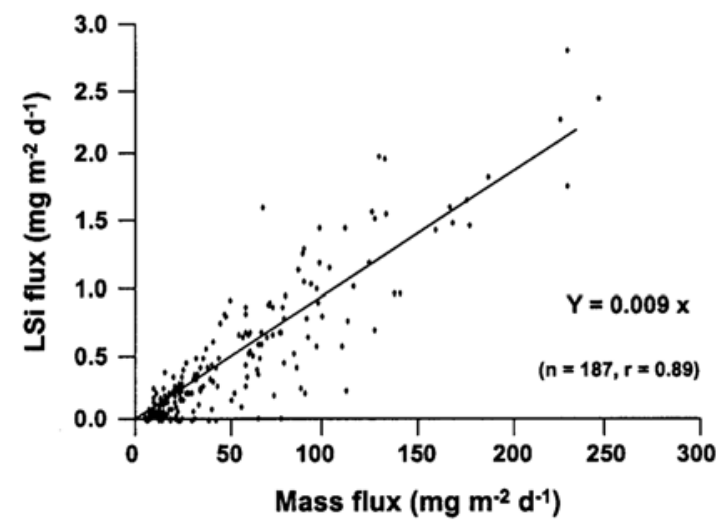

C

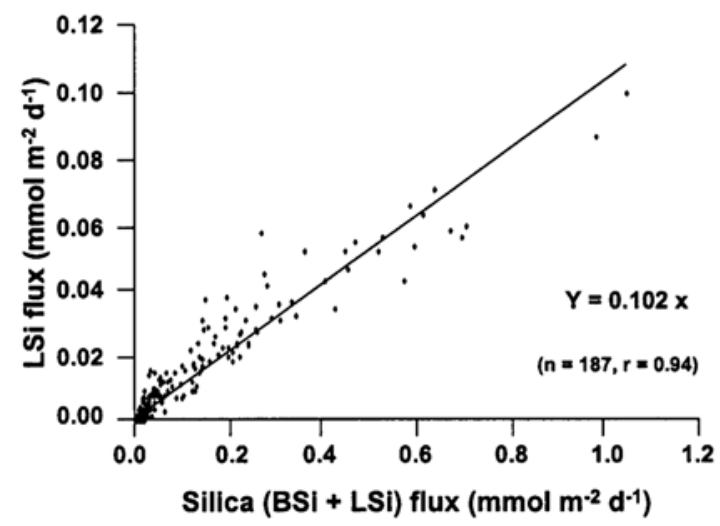

Figure 6. (a) BSi fluxes versus mass fluxes, (b) LSi fluxes versus mass fluxes, and (c) LSi fluxes versus total silica (BSi + LSi) fluxes from February 2001 to February 2002 (bulk data). Data from southwest sediment traps and $400 \mathrm{~m}$ northwest sediment traps were excluded from the relationships because records have been interrupted on the annual cycle due to logistical problems.

NABE (North Atlantic Bloom Experiment) $47^{\circ} 3^{\prime} \mathrm{N}$ station $\left(0.351 \mathrm{mmol} \mathrm{m}^{-2} \mathrm{~d}^{-1}\right)$ and at the southern NABE $33^{\circ} 5^{\prime} \mathrm{N}$ station $\left(0.111 \mathrm{mmol} \mathrm{m}^{-2} \mathrm{~d}^{-1}\right)$. However, as most of the publications treating about BSi export fluxes present bulk data we use in the following section and in the corresponding table our BSi flux values non corrected from ${ }^{230} \mathrm{Th}$ trapping efficiency. These $\mathrm{BSi}$ flux values averaged over the area were $0.093 \mathrm{mmol} \mathrm{m}^{-2} \mathrm{~d}^{-1}$ at $400 \mathrm{~m}$ and $0.104 \mathrm{mmol} \mathrm{m}^{-2} \mathrm{~d}^{-1}$ at $1000 \mathrm{~m}$. These data along with previous data non corrected from trapping efficiency from North Atlantic ocean are presented in Table 3. They are of the same order of magnitude as fluxes estimated for the oligotrophic Sargasso Sea during BATS (Bermuda Atlantic Time series) [Brzezinski and Nelson, 1995] or at the lower-latitude Demerara Abyssal Plain site [Honjo et al., 1982], 1.4-fold lower than fluxes at the northern NABE mooring $\left(47^{\circ} 3^{\prime} \mathrm{N}\right)$ and 1.5 -fold lower than the ones estimated at the northernmost PAP (Porcupine Abyssal Plain) station [Lampitt et al., 2001]. Although these data are underestimated because trapping efficiency, which was not available for the whole data, was not taken into account, it seems that POMME BSi fluxes are higher than the ones recorded at the southern NABE site [Honjo and Manganini, 1993]. This observation is consistent with the existence of a south-north positive gradient of biogenic silica export in the eastern Atlantic basin which parallels the gradient of primary production [Longhurst, 1995]. Thus BSi fluxes recorded in the Northeast Atlantic area of POMME are relatively low and more comparable to typical oligotrophic areas such as the Sargasso Sea and the tropical Atlantic Ocean. Moreover the findings are compatible with other oligotrophic regions such as the Western equatorial Atlantic where values ranging between 0.107 and $0.142 \mathrm{mmol} \mathrm{Si} \mathrm{m}{ }^{-2} \mathrm{~d}^{-1}$ have been recorded at 500-850 m depth [Romero et al., 2000] or the North Pacific Gyre A Long-term Oligotrophic Habitat Assessment (ALOHA) site of the Hawaii Ocean Time-Series (HOT) program where a value as low as $0.065 \mathrm{mmol} \mathrm{Si} \mathrm{m}{ }^{-2} \mathrm{~d}^{-1}$ has been estimated at $150 \mathrm{~m}$ depth by Scharek et al. [1999]. Finally, POMME BSi fluxes are clearly lower than the Global Ocean average of $0.411 \mathrm{mmol} \mathrm{m}^{-2} \mathrm{~d}^{-1}$ that however takes into account of the highest fluxes classically encountered in the Southern Ocean [Nelson et al., 2002]. However, the Northeast Atlantic is generally considered as a rather mesotrophic system. This is confirmed by the annual extrapolated estimate of primary production for the study area of $204 \mathrm{~g} \mathrm{C} \mathrm{m}^{-2} \mathrm{yr}^{-1}$ [Fernández et al., 2005]. This is compatible with previous estimates of $122 \mathrm{~g} \mathrm{C} \mathrm{m}^{-2} \mathrm{yr}^{-1}$ for the NAST (North Atlantic Subtropical Gyre) East province and $240 \mathrm{~g} \mathrm{C} \mathrm{m}^{-2} \mathrm{yr}^{-1}$ for the NADR (North Atlantic Drift) province [Longhurst et al., 1995] as the study area is located at the transition between these two provinces (the separation lies at $\sim 40^{\circ} \mathrm{N}$ ). Although this region is mesotrophic in terms of carbon uptake rates, BSi production rates are low $\left(0.04-11.20 \mathrm{mmol} \mathrm{m}^{-2} \mathrm{~d}^{-1}\right)$ and close to oligotrophic gyre values [Leblanc et al., 2005]. Indeed, the diatom production is subject to a Si limitation as evidenced by kinetic studies of silica uptake. On the overall area, specific silica uptake rates $V_{\mathrm{Si}}$ (measured at $20 \mathrm{~m}$ in winter and spring 2001) are limited to $11-55 \%$ of their potential maximum specific silica uptake rates $V_{\max }$. Precisely, as evidenced by Blain et al. [2004] diatoms are colimited by iron and silicon.

[32] The annual mass fluxes (corrected from ${ }^{230} \mathrm{Th}$ calibration) are 140 and $144 \mathrm{mg} \mathrm{m}^{-2} \mathrm{~d}^{-1}$ at 400 and $1000 \mathrm{~m}$ respectively (averaged from Table 2) from this study. This is rather equivalent to the estimates of the northern NABE station $\left(138 \mathrm{mg} \mathrm{m}^{-2} \mathrm{~d}^{-1}\right)$ than comprising, unlike the annual BSi fluxes, the estimates of the northern and the southern stations at $1000 \mathrm{~m}$. 

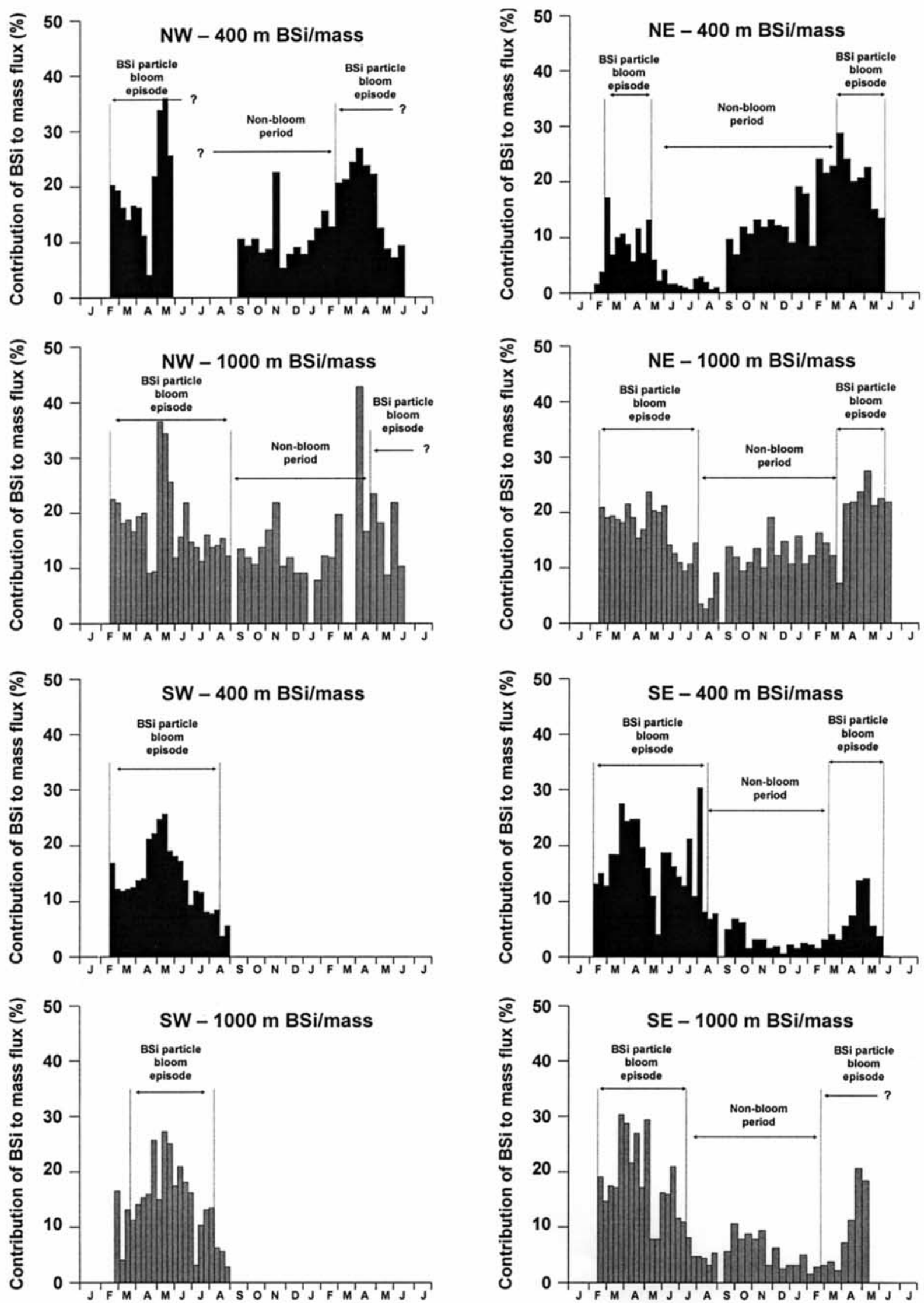

Figure 7. Seasonal evolution of the BSi contributions to mass fluxes (details as in Figure 4). 
Table 3. BSi Flux Records (Uncorrected for Trap Efficiency) at 400 and $1000 \mathrm{~m}$ Depths in the North Atlantic ${ }^{\mathrm{a}}$

\begin{tabular}{|c|c|c|c|c|}
\hline \multirow[b]{2}{*}{ Location } & \multirow[b]{2}{*}{ Date } & \multicolumn{2}{|c|}{$\begin{array}{l}\text { BSi Fluxes, } \\
\text { mmol m }{ }^{-2} \mathrm{~d}^{-1}\end{array}$} & \multirow[b]{2}{*}{ Reference } \\
\hline & & $400 \mathrm{~m}$ & $1000 \mathrm{~m}$ & \\
\hline PAP, $48^{\circ} 5^{\prime} \mathrm{N}-16^{\circ} 3^{\prime} \mathrm{W}$ & interannual average $(1997,1998,1999)$ & & $0.160^{\mathrm{b}}$ & Lampitt et al. [2001] \\
\hline \multirow[t]{4}{*}{$\mathrm{NABE}, 47^{\circ} 3^{\prime} \mathrm{N}-19^{\circ} 3^{\prime} \mathrm{W}$} & prebloom & & 0.048 & Honjo and Manganini [1993] \\
\hline & bloom & & 0.374 & Honjo and Manganini [1993] \\
\hline & postbloom & & 0.091 & Honjo and Manganini [1993] \\
\hline & annual average $(1989-1990)$ & & 0.144 & Honjo and Manganini [1993] \\
\hline \multirow[t]{5}{*}{ POMME, $38^{\circ}-45^{\circ} \mathrm{N}, 16^{\circ}-22^{\circ} \mathrm{W}$} & northeast & 0.039 & 0.111 & this study \\
\hline & northwest & & 0.111 & this study \\
\hline & southeast & 0.147 & 0.090 & this study \\
\hline & southwest & & & this study \\
\hline & annual average (2001-2002) & 0.093 & 0.104 & this study \\
\hline \multirow[t]{4}{*}{$\mathrm{NABE}, 33^{\circ} 5^{\prime} \mathrm{N}-19^{\circ} 3^{\prime} \mathrm{W}$} & prebloom & & 0.027 & Honjo and Manganini [1993] \\
\hline & bloom & & 0.145 & Honjo and Manganini [1993] \\
\hline & postbloom & & 0.010 & Honjo and Manganini [1993] \\
\hline & annual average (1989-1990) & & 0.067 & Honjo and Manganini [1993] \\
\hline BATS, $31^{\circ} 5^{\prime} \mathrm{N}-64^{\circ} 1^{\prime} \mathrm{W}$ & $1991-1992$ & $0.085^{\mathrm{c}}$ & & Brzezinski and Nelson [1995] \\
\hline Demerara, $13^{\circ} 3^{\prime} \mathrm{N}-54^{\circ} 0^{\prime} \mathrm{W}$ & $1977-1978$ & 0.096 & 0.085 & Honjo et al. [1982] \\
\hline
\end{tabular}

${ }^{\text {a} P A P, ~ P o r c u p i n e ~ A b y s s a l ~ P l a i n ; ~ N A B E, ~ N o r t h ~ A t l a n t i c ~ B l o o m ~ E x p e r i m e n t ; ~ P O M M E, ~ P r o g r a m m e ~ O c e ́ a n ~ M u l t i d i s c i p l i n a i r e ~ M e ́ s o ~ E c h e l l e ; ~ B A T S, ~}$ Bermuda Atlantic time series. Boldface values are averaged over the study area and over a complete year (annual average).

${ }^{\mathrm{b}}$ According to the authors, PAP fluxes at $1000 \mathrm{~m}$ are likely to be underestimated.

${ }^{\mathrm{c}}$ BATS flux data were estimated at $300 \mathrm{~m}$ depth.

[33] The $18.3 \%$ contribution of BSi to the annual mass flux is of the same order of magnitude as the $17.8 \%$ annual BSi contribution to mass flux estimated during NABE [Honjo and Manganini, 1993]. This could reflect the importance of the siliceous plankton components to the downward export flux. Leblanc et al. [2005] show that diatom contribution to primary production over the study area is in the range $2-37 \%$ throughout the year 2001 apart from a northern site $\left(43.5^{\circ} \mathrm{N}\right)$ where it is $100 \%$ during spring.

[34] Annual LSi fluxes (averaged from Table 2/corrected from ${ }^{230} \mathrm{Th}$ trapping efficiency) range between $0.029 \mathrm{mmol}$ $\mathrm{m}^{-2} \mathrm{~d}^{-1}$ at $400 \mathrm{~m}$ to $0.054 \mathrm{mmol} \mathrm{m}^{-2} \mathrm{~d}^{-1}$ at $1000 \mathrm{~m}$. Otherwise, our bulk LSi flux values (range, averaged over the area: $0.012 \mathrm{mmol} \mathrm{m}^{-2} \mathrm{~d}^{-1}$ at $400 \mathrm{~m}$ and $0.018 \mathrm{mmol} \mathrm{m}^{-2} \mathrm{~d}^{-1}$ at $1000 \mathrm{~m}$ ) are comparable with the bulk annual LSi flux of $0.022 \mathrm{mmol} \mathrm{m} \mathrm{m}^{-2} \mathrm{~d}^{-1}$ measured at $300 \mathrm{~m}$ at BATS [Brzezinski and Nelson, 1995]. At the latter site LSi export peaks of $0.080 \mathrm{mmol} \mathrm{m}^{-2} \mathrm{~d}^{-1}$, which are consistent with our LSi export peak values (0.036-0.125 mmol m $\mathrm{m}^{-2} \mathrm{~d}^{-1}$ ), have been related to Saharan dust input episodic events. The LSi export peaks recorded in our study also probably originate from Saharan dust inputs as a strong Saharan event took place in the area at mid-February 2001 and Guieu et al. [2005] have shown that the $\mathrm{Al} / \mathrm{Fe}$ ratio in some trap samples is typical of the $\mathrm{Al} / \mathrm{Fe}$ ratio of Saharan aerosols.

4.2. Coupling of Biogenic and Lithogenic Silica Fluxes

[35] Figure 8 illustrates the strong relationship between biogenic and lithogenic silica export fluxes in our study $(r=$ $0.88, n=311$ ). Such a relationship can arise from very different processes: the scavenging of lithogenic particles by sinking biogenic material and the limitation of siliceous phytoplankton productivity by some lithogenic constituents, namely trace metals released from dust particles. None of these processes can be eliminated in our study. The exact simultaneity of LSi export peaks with the BSi ones favors the scavenging hypothesis, yet, at the same time, Blain et al.
[2004] have provided experimental evidence of silicon/iron colimitation of diatom growth in the POMME area. We have outlined on Figure 8 two individual data points which exhibit especially high LSi levels as compared to BSi and could correspond to Saharan inputs. These two points correspond to the high LSi export peaks recorded at $400 \mathrm{~m}$ at the southwest station from 22 February to 3 March and at the northwest station from 18 to 26 March 2001. These latter events parallel a Saharan dust input event observed by satellite imagery by mid-February 2001 . The delay before the occurrence of LSi export peaks at the two sites could be related to particle settling velocity which was higher at the southwest station [Guieu et al., 2005].

\subsection{Spatiotemporal Variability}

[36] Mass, BSi, and LSi fluxes show a similar spatial and temporal pattern which is confirmed by the statistically

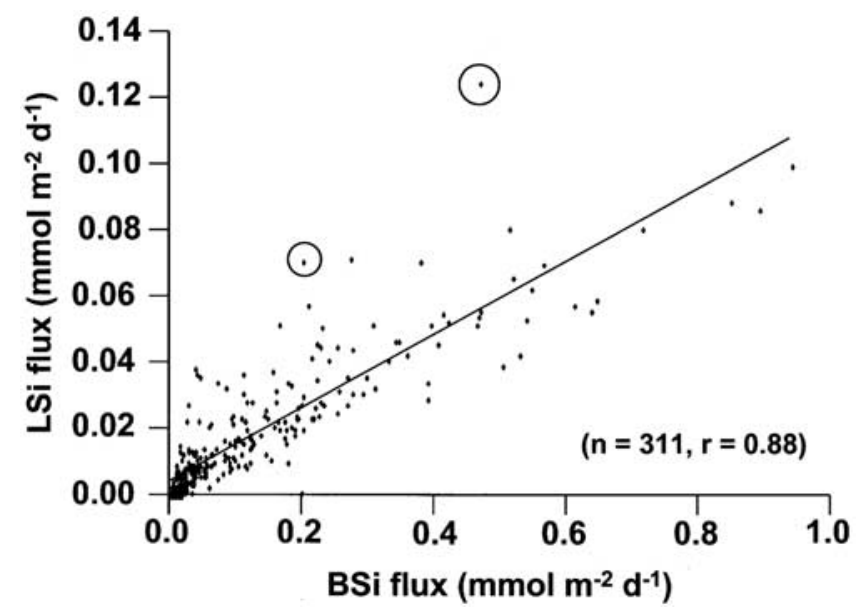

Figure 8. Linear correlation between BSi and LSi fluxes. The two circled data points correspond to samples with high LSi level as compared to BSi (see text for details). 
significant correlations obtained between these variables (Figure 6).

[37] The seasonal variability of BSi export fluxes as well as the contribution of BSi to mass fluxes is the expression of the siliceous phytoplankton seasonal variability observed at the surface: BSi stocks and production measured in 2001 are quite weak during winter (February-March), show a straight increase during spring (April-May) and are negligible during autumn (September-October). For the overall study area, respective integrated values $(0-80 \mathrm{~m})$ of $\mathrm{BSi}$ stock and silica uptake rates are $4-8 \mathrm{mmol} \mathrm{Si} \mathrm{m}^{-2}$ and $0.50-1.45 \mathrm{mmol} \mathrm{Si} \mathrm{m}^{-2} \mathrm{~d}^{-1}$ in winter, $10-61 \mathrm{mmol} \mathrm{Si} \mathrm{m}^{-2}$ and $0.67-11.20 \mathrm{mmol} \mathrm{Si} \mathrm{m} \mathrm{m}^{-1}$ in spring, and 2$3 \mathrm{mmol} \mathrm{Si} \mathrm{m}{ }^{-2}$ and $0.04-0.08 \mathrm{mmol} \mathrm{Si} \mathrm{m}^{-2} \mathrm{~d}^{-1}$ in autumn [Leblanc et al., 2005]. As already mentioned, our study area is part of the NAST East and NADR provinces defined by Longhurst [1995]. Classically, a latitudinal lag time in the triggering of the spring bloom signal characterizes the latter provinces of the Westerlies domain: the spring bloom begins from March to April at the south and progresses toward the north as the surface water progressively stratifies due to the combined effects of decreasing wind speeds and increasing solar warming. D. Bourras et al. (Response of the atmospheric boundary layer to a mesoscale oceanic eddy in the northeast Atlantic, submitted to Journal of Geophysical Research, 2004) describe the environmental conditions that have prevailed from 1 February to 30 April 2001. During these 3 months, average SST increases by $0.4^{\circ} \mathrm{C}$ while average wind intensity decreases by $\sim 1.1 \mathrm{~m} \mathrm{~s}^{-1}$, and the mean values are near climatological values $\left(\sim 14.4^{\circ} \mathrm{C}\right.$ and $\left.8-9 \mathrm{~m} \mathrm{~s}^{-1}\right)$. However by looking at sediment flux data from our study, it is quite obvious that they do not parallel the latitudinal propagation of the spring bloom, which enlightens an apparent uncoupling between surface production and vertical export. The expected northward procession of the onset of the spring particle bloom episode (with a speed of $26 \mathrm{~km} \mathrm{~d}^{-1}$ estimated by Honjo and Manganini [1993]) is not clear; even the observation of earlier BSi export peaks at the northern stations as compared to the southern ones is contradictory to our expectations.

[38] The $2001 \mathrm{BSi}$ particle bloom episode provides more than $80 \%$ of the annual average BSi flux at all stations except at the northeast station at $400 \mathrm{~m}$ where it provides only $69 \%$ which illustrates the contrast between bloom and non bloom BSi particle flux episodes.

[39] There is a notable variability in the timing, the duration and the magnitude of the spring bloom silica fluxes between the years 2001 and 2002. After February 2002, mass fluxes were not calibrated by ${ }^{230} \mathrm{Th}$ measurements; however, as suggested by Guieu et al. [2005] we can compare, although it may introduce some bias for each trap, the two following years considering the trapping efficiency would not be very different as there is little interannual changes in the trapping efficiency. With regards to the timing of BSi export fluxes, the 2002 spring particle bloom episode occurs 1 month later as compared to 2001 . The particle bloom episode seems to be shorter in 2002 as compared to 2001 and thus 2002 silica fluxes are much lower than 2001 fluxes except at the northeast station at $400 \mathrm{~m}$ where silica fluxes tend to be higher (Figures 4 and 5). The comparison of the total amount of $\mathrm{BSi}$ collected during the two recorded spring particle bloom episodes shows that, with reference to the year 2001, the year 2002 fluxes are $90 \%$ lower at the southeast station at $400 \mathrm{~m}, 24 \%$ lower at the northeast station at $1000 \mathrm{~m}$ whereas they are $75 \%$ higher at the northeast station at $400 \mathrm{~m}$. The variability between the years 2001 and 2002 is thus extremely pronounced, especially at the southeast station, and for the overall study area largely exceeding the global average interannual variability of $40 \%$ reported by Ragueneau et al. [2002]. Boyd and Newton [1995] have already documented the importance of the size structure of the spring bloom diatom populations in the Northeast Atlantic on the downward flux of particulate material. Following Boyd and Newton [1995] the variability between the 2 consecutive years over the POMME area can be assigned to interannual variations in phytoplankton specific composition and size structure. Year-toyear differences in thermal stratification and vertical density structure resulting from meteorological parameter variations (e.g., wind stress, insolation) may account for the interannual variation in siliceous phytoplankton communities. In spite of this year-to-year variability, episodes of high $\mathrm{BSi}$ fluxes remain associated with the spring productive period.

[40] The differences observed between the four mooring sites must also be interpreted in terms of spatial variability as the study area is divided into two domains by a frontal zone. The frontal structure appears as an hydrological front. The mixed layer depths are significantly shallower south of $41^{\circ} \mathrm{N}$ (around $125 \mathrm{~m}$ ) as compared to the northern values (around $144 \mathrm{~m}$ ) in winter 2001. The front acts as a boundary between water masses marked by temperature and salinity increasing at the surface from north to south. Differences between each side of the front vary from $0.1^{\circ}$ to $0.5^{\circ} \mathrm{C}$ throughout the year 2001 [Fernández et al., 2005]. The frontal area is centered around $41^{\circ} \mathrm{N}$ and is defined as the region where the meridional gradient is the more pronounced. Throughout the year 2001, it spread between $38^{\circ}-42^{\circ} \mathrm{N}$ in winter, $38^{\circ}-41^{\circ} \mathrm{N}$ in spring, and $39^{\circ}-43^{\circ} \mathrm{N}$ in autumn [Reverdin et al., 2005]. Strong quasi-permanent eastward currents are associated with the frontal area. The general nutrient distribution also matches the frontal structure: the supply of nutrients to the surface water is lower in the southern domain because of a shallower winter mixing as compared to the northern domain. The average $\mathrm{NO}_{3}^{-}$ concentrations over the euphotic zone are at least $40 \%$ higher in the northern domain as compared to the southern domain all over 2001 [Fernández et al., 2005]. The 0-80 m integrated $\mathrm{Si}(\mathrm{OH})_{4}$ stocks in winter are also around $49 \%$ higher in the northern domain as compared to the southern one [Leblanc et al., 2005]. With regard to biology although there is not an evident south-north gradient in primary production and chlorophyll fields, there is a pronounced south-north difference in the siliceous biomass with the northern domain experiencing the higher stocks of both BSi and fucoxanthin (a diagnostic pigment of diatoms [Jeffrey, 1997]) in connection with the nutrient availability controlled by the depth of the winter mixed layer [Fernández et al., 2005; Leblanc et al., 2005]. Results obtained at three stations covering the south-north gradient and located at $40^{\circ} \mathrm{N}, 41.75^{\circ} \mathrm{N}$ and $43.5^{\circ} \mathrm{N}$ indicate that the spring BSi biomass value integrated on the $0-80 \mathrm{~m}$ layer is 10,25 and 
$61 \mathrm{mmol} \mathrm{Si} \mathrm{m}^{-2}$, respectively. The spring biogenic silica production rates are $0.67,1.30$ and $11.20 \mathrm{mmol} \mathrm{m}^{-2} \mathrm{~d}^{-1}$ at the three latter sites, respectively. The biogenic silica southnorth positive gradient is also revealed by a south-north fucoxanthin positive gradient. The $0-80 \mathrm{~m}$ layer integrated values of fucoxanthin are $2.03,3.02$ and $6.55 \mathrm{mg} \mathrm{m}^{-2}$ at $40^{\circ} \mathrm{N}, 41.75^{\circ} \mathrm{N}$ and $43.5^{\circ} \mathrm{N}$ respectively in winter and 4.07 , 8.87 , and $15.25 \mathrm{mg} \mathrm{m}^{-2}$ in spring at these three respective stations. This is in accordance with a greater supply of silicic acid in the northern area as values of 135,185 and $200 \mathrm{mmol} \mathrm{Si} \mathrm{m}^{-2}$ for the $0-80 \mathrm{~m}$ integrated initial silicic acid stocks were measured in winter at these three respective stations [Leblanc et al., 2005]. The clear south-north gradient in silica production is poorly paralleled by carbon primary production. This apparent uncoupling between silica and carbon production is also evidenced by the south-north uncoupling between silicic acid and nitrate consumption. At a northern domain station at $43.5^{\circ} \mathrm{N}$, between winter and spring 2001 the respective consumption of $\mathrm{Si}(\mathrm{OH})_{4}$ and $\mathrm{NO}_{3}^{-}$are 95.4 and $183.1 \mathrm{mmol} \mathrm{m}^{-2}$ while at a southern domain station at $40^{\circ} \mathrm{N}$ they are respectively 17.6 and $137.3 \mathrm{mmol} \mathrm{m}^{-2}$. This is a strong indication of the occurrence of a bloom not dominated by diatoms in the southern area. If we consider the bulk data, mass, BSi, and LSi export fluxes recorded at $400 \mathrm{~m}$ do not follow the same trend as during the 2001 spring bloom period as well as on an annual average (not shown, except for BSi in Table 3). Bulk fluxes are even higher at the southern stations. This is due, probably in a large proportion, to the different trapping efficiencies encountered. When applying to the bulk fluxes the ${ }^{230} \mathrm{Th}$ calibration, the south-north difference is minimized. The relatively low trapping efficiencies can be in relation with hydrodynamic features. This is particularly interesting at the northeast station $400 \mathrm{~m}$ trap, which experienced the lower trapping efficiency (18.5\%) and where the highest current velocities were observed [Guieu et al., 2005]. The ${ }^{230} \mathrm{Th}$ correction restore higher mass fluxes at $400 \mathrm{~m}$ in the northern domain as well as for annual mass flux or export peaks. However, although the corrections from ${ }^{230} \mathrm{Th}$ calibration limit the south-north difference observed with bulk data, it does not restore higher silica (both BSi and LSi) export fluxes at $400 \mathrm{~m}$ in the northern domain as for mass fluxes. At $400 \mathrm{~m}$, the corrected silica fluxes are quite similar between the northern and southern stations and even seem still slightly higher in the southern area looking at the annual BSi and LSi export fluxes at the southeast station versus at the northeast one (Table 2). Yet, in addition to being more productive the diatoms are also larger in the northern domain as compared to the southern one so that one can expect that they have a much better chance of settling out rapidly of the surface layer. Diatom associations in the northern domain are dominated in spring by large $(>10 \mu \mathrm{m})$ colonies of the small pennate diatoms of the Pseudo-nitzschia delicatissima complex while the southern diatom populations are dominated by the same complex with however isolated cells. In the southern area, the total phytoplankton community is dominated by the coccolithophorid Emiliana huxleyi. Size fractionated data indicate that the contribution of large diatoms $(>10 \mu \mathrm{m})$ to $\mathrm{BSi}$ biomass and to $\mathrm{BSi}$ production accounts for $76 \%$ and $91 \%$ respectively at the northern site $\left(43.5^{\circ} \mathrm{N}\right)$ while it accounts for $58 \%$ and $59 \%$ respectively at the southern site $\left(40^{\circ} \mathrm{N}\right)$ during the productive season [Leblanc et al., 2005]. Given that (1) BSi export fluxes are quite equivalent or even, considering annual export flux estimates, quite higher in the southern domain as compared to the northern one at $400 \mathrm{~m}$ and that (2) BSi biomass, BSi production and occurrence of large diatoms in the surface are much more important in the northern domain, our observations can be interpreted as a southward matter transfer from the northern more productive area to the southern more oligotrophic area between the surface and $400 \mathrm{~m}$ depth. We cannot explain this transfer of matter as related to a simple isopycnal vertical transport because the temporal evolution of isopycnals does not evidence any strong signal of subduction all over the study period. So, we have to consider that an horizontal $0-400 \mathrm{~m}$ depth advective transport related to the southern branch of the North Atlantic Current which flows southward crossing the study area (Figure 1a) combines with siliceous phytoplankton sedimentation to produce this suspended matter transfer between north and south. Some indications are obtained from the results of a tracer transport model (M. Lévy, LODYC Paris, personal communication, 2004) which have evidenced a southward transport during a short period in March-April. This southward transport or at least the southwestward transport has also been evidenced by Assenbaum and Reverdin [2005] and by Reverdin et al. [2005] through circulation analyses and mapping by objective analysis methods. These authors show that the front acts as a barrier to the diffusion of tracers, except in March-April 2001. For this period, the evolution of the water mass properties south of the front suggests some intrusions of water with more northern properties. Between the winter and spring hydrological surveys the hightemperature, low-oxygen winter water disappears from the southern domain (western part) and is replaced by the spring colder more oxygenated water most likely originating from the northern area. This interpretation is supported by analyses of simulated trajectories which suggest the intrusion of water originating from the vicinity of the front that spreads in the southern domain. Moreover, the eddy kinetic energy (EKE) in the frontal region (near $41^{\circ} \mathrm{N}$ ) shows a maximum in March-April suggesting a greater mixing resulting in a temporary suppression of the isolation between the northern and the southern domains which allows some water to cross the frontal area. The EKE reaches $140 \mathrm{~cm}^{2} \mathrm{~s}^{-2}$ between March and April, a very high value as compared to the range $30-100 \mathrm{~cm}^{2} \mathrm{~s}^{-2}$ estimated for the rest of the study [see Assenbaum and Reverdin, 2005, Figure 11]. If such an advective north to south transport occurs in spring 2001, it can explain why the proportion of $\mathrm{BSi}$ is quite low at the northeast station at $400 \mathrm{~m}(10 \%)$ during this period although the northern phytoplanktonic community is quite $100 \%$ composed by diatoms [Leblanc et al., 2005]. Also, if such an advective north to south transport affects the 0-400 m superficial layer it can explain why the $1000 \mathrm{~m}$ depth BSi and LSi export fluxes are higher than the $400 \mathrm{~m}$ depth ones at the northern stations by hypothesizing that these northern stations received at $1000 \mathrm{~m}$ depth an advected material originating from a more northern and more productive area. Examples of such major advective inputs have already been shown to account for significant increases in flux with depth 
in the Panama Basin [Honjo, 1982; Honjo et al., 1982] or the Guinea Basin [Wefer and Fisher, 1993].

[41] Some individual mass and BSi export peaks could also reflect the importance of wind mixing in the vertical transport process. The northeast Atlantic is characterized by episodic wind events [Stramska et al., 1995] and a meteorological buoy located in the study area $\left(41.6^{\circ} \mathrm{N}, 20.0^{\circ} \mathrm{W}\right)$ has recorded highly variable winds (range $0-20 \mathrm{~m} \mathrm{~s}^{-1}$ ) from January to August 2001 (http://www.lodyc.jussieu.fr/ POMME). Pesant et al. [2002] have shown that increased mixing has a big importance for the removal of phytoplankton from the surface. Wind-triggered events of phytoplankton downward flux can also be responsible for the occurrence of the two sedimentation episodes of spring 2001 as especially high winds (up to $19 \mathrm{~m} \mathrm{~s}^{-1}$ ) are recorded in the area by mid-April.

\subsection{Fate of Surface BSi Production}

[42] We have attempted to compare the BSi export fluxes with the production of silica at the surface. Such a linking is not easy because $\mathrm{BSi}$ production and $\mathrm{BSi}$ export are measured at different sites and sometimes within different eddy fields. The comparison can be done by two methods: (1) the comparison of the consumption of $\mathrm{Si}(\mathrm{OH})_{4}$ in the mixed layer with the BSi export fluxes during the investigated period and (2) the comparison between direct $\mathrm{BSi}$ production values in the mixed layer [Leblanc et al., 2005] and BSi export fluxes estimated during the time interval following the discrete production measurement. Comparisons have been made between data from the northeast and southeast trap stations where sampling was not interrupted during a complete annual cycle and the production stations located at $43.5^{\circ} \mathrm{N}$ and $40^{\circ} \mathrm{N}$ which were visited in winter and spring 2001. Results (from both bulk and ${ }^{230} \mathrm{Th}$ corrected BSi export flux data) are reported in Table 4. At the northeast station, there is a clear uncoupling between the export of BSi production at 400 and $1000 \mathrm{~m}$ with more locally produced $\mathrm{BSi}$ export at the deeper trap. Even if we consider the large undertrapping of the $400 \mathrm{~m}$ trap at this northeast station (i.e., considering the BSi fluxes corrected from ${ }^{230} \mathrm{Th}$ trapping efficiencies) the export of BSi production remains higher at $1000 \mathrm{~m}$ as compared to $400 \mathrm{~m}$. This runs counter the verticality in the BSi export at this northern station and may reflect advective processes. There is a quite good agreement between the estimates of export of $\mathrm{BSi}$ production from winter production and from winter to spring silicic acid consumption. The export of BSi production seems lower during spring; however the site used for the spring comparison is characterized by a particular high $\mathrm{BSi}$ production rate. At the southeast station, with the exception of the winter season, there is less export of locally produced $\mathrm{BSi}$ at $1000 \mathrm{~m}$ as compared to $400 \mathrm{~m}$. This result does not exclude the verticality in the BSi export between 400 and $1000 \mathrm{~m}$ at this southern station. In winter estimates of exported BSi production (from bulk data) are quite similar at the two depths which can reflect lower BSi dissolution rates between the surface and $400 \mathrm{~m}$ during this season due to low temperatures [Kamatani, 1982]. In spring there is an important proportion of locally produced BSi (from bulk data) that is exported; this is somewhat surprising considering the low $\mathrm{BSi}$ production in the southern domain. With regard to ${ }^{230} \mathrm{Th}$ corrected data in spring and 
also to the silicic acid consumption (from both bulk and ${ }^{230} \mathrm{Th}$ corrected data) there is a strong uncoupling between $\mathrm{BSi}$ production and export as the export of BSi is up to 1.3to threefold higher than the BSi production in the surface layer. This inconsistency again provides an indication of the importance of advective processes at this southern station. In the POMME area of investigation, the vertical exportation processes are likely complex and very probably strongly influenced by mesoscale current fields. For this reason, we have to be careful because none of the methods for linking $\mathrm{BSi}$ production versus $\mathrm{BSi}$ export is totally adequate nor takes into account of the mesoscale eddy fields. The method using the consumption of nutrients assumes no input or output by advection or diffusion in the surface mixed layer which is obviously unrealistic. On the other hand, the use of a discrete measurement of BSi production is not representative of a long period because production events are known to vary on small timescales, showing large day-to-day variations, especially during the spring transition period.

\section{Conclusions}

[43] In the northeast Atlantic investigated area, the 2001 annual average BSi export flux is estimated to range between $0.240-0.316 \mathrm{mmol} \mathrm{m}{ }^{-2} \mathrm{~d}^{-1}\left({ }^{230} \mathrm{Th}\right.$ corrected data) and is quite comparable to classical oligotrophic area fluxes. The annual average LSi export flux is estimated to range between and $0.029-0.054 \mathrm{mmol} \mathrm{m}{ }^{-2} \mathrm{~d}^{-1}\left({ }^{230} \mathrm{Th}\right.$ corrected data). We have found a strong coupling between BSi and LSi fluxes which suggests the importance of LSi scavenging processes and the limitation of BSi production by lithogenic supplies, both processes which are not mutually exclusive. The particle export dynamics in the northeast Atlantic are characterized by a strong seasonal variability. The BSi fluxes are mirroring the seasonal variability of diatom blooms: both production and export of $\mathrm{BSi}$ are maximum in spring which is in accordance with the general fast sinking rates of diatoms. However the spatial variability of $400 \mathrm{~m} \mathrm{BSi}$ fluxes does not correspond to the south-north positive production gradient at the surface. Quite higher flux records at $400 \mathrm{~m}$ in the southern, less productive, domain can be related to a southward advective transport from the northern domain between the surface and $400 \mathrm{~m}$.

[44] Acknowledgments. The POMME program was managed by Laurent Mémery and Gilles Reverdin and received support from CNRS, IFREMER, Meteo-France, and SHOM. The authors are indebted to the captains and crews of the $\mathrm{R} / \mathrm{V}$ L'Atalante, the R/V Thalassa, and the $\mathrm{R} / \mathrm{V}$ d'Entrecasteaux. Data analyses were funded by grants from the French research programs of INSU-CNRS: PROOF (PROcessus biogéochimiques dans l'Océan et Flux) and PATOM (Programme Atmosphère et Océan Multi-Echelles). The authors also acknowledge two anonymous reviewers and Stéphane Blain for their useful and constructive comments, which helped to improve the manuscript.

\section{References}

Antia, A. N., et al. (2001), Basin-wide particulate carbon flux in the Atlantic Ocean: Regional export patterns and potential for atmospheric $\mathrm{CO}_{2}$ sequestration, Global Biogeochem. Cycles, 15, 845-862.

Assenbaum, M., and G. Reverdin (2005), Near real-time analyses of the mesoscale circulation during the POMME experiment, Deep Sea Res., in press.

Blain, S., C. Guieu, H. Claustre, K. Leblanc, T. Moutin, B. Quéguiner, J. Ras, and G. Sarthou (2004), Availability of iron and major nutrients for phytoplankton in the north-east Atlantic Ocean, Limnol. Oceanogr., 49, 2095-2104

Boyd, P., and P. Newton (1995), Evidence of the potential influence of phytoplanktonic community structure on the interannual variability of particulate organic carbon flux, Deep Sea Res., Part I, 46, 619-639.

Broecker, W. S. (1991), The great ocean conveyor, Oceanography, 4, 7989

Brzezinski, M. A., and D. M. Nelson (1995), The annual silica cycle in the Sargasso Sea near Bermuda, Deep Sea Res., Part I, 42, 1215-1237.

Buesseler, K. O. (1998), The decoupling of production and particulate export in the surface ocean, Global Biogeochem. Cycles, 12, 297-310.

Claustre, H., A. Morel, S. B. Hooker, M. Babin, D. Antoine, K. Oubelkheir, A. Bricaud, K. Leblanc, B. Quéguiner, and S. Maritorena (2002), Is desert dust making oligotrophic waters greener?, Geophys. Res. Lett., 29(10), 1469, doi:10.1029/2001GL014056.

DeMaster, D. J. (1981), The supply and accumulation of silica in the marine environment, Cosmochim. Acta, 45, 1715-1732.

Esaias, W. E., G. C. Feldman, C. R. McClain, and J. A. Elrod (1986), Monthly satellite-derived phytoplankton pigment distribution for the North Atlantic Ocean Basin, Eos Trans. AGU, 67(44), 835-837.

Fernández, C. I., P. Raimbault, N. Garcia, P. Rimmelin, and G. Caniaux (2005), An estimation of annual new production and carbon fluxes in the northeast Atlantic Ocean during 2001, J. Geophys. Res., doi:10.1029/ 2004JC002616, in press.

Guieu, C., M. Roy-Barman, N. Leblond, C. Jeandel, M. Souhaut, B. Le Cann, A. Dufour, and C. Bournot (2005), Vertical particle flux in the northeast Atlantic Ocean (POMME experiment), J. Geophys. Res., doi:10.1029/2004JC002672, in press.

Honjo, S. (1982), Seasonality and interaction of biogenic and lithogenic particulate flux at the Panama Basin, Science, 218, 883-884.

Honjo, S., and S. J. Manganini (1993), Annual biogenic particle fluxes to the interior of the North Atlantic Ocean studied at $34^{\circ} \mathrm{N} 21^{\circ} \mathrm{W}$ and $48^{\circ} \mathrm{N}$ $21^{\circ} \mathrm{W}$, Deep Sea Res., Part I, 40, 587-607.

Honjo, S., S. J. Manganini, and J. J. Cole (1982), Sedimentation of biogenic matter in the deep ocean, Deep Sea Res., Part A, 29, 609-625.

Jeffrey, S. W. (1997), Application of pigment methods to oceanography, in Phytoplankton Pigments in Oceanography: Guidelines to Modern Methods, edited by S. W. Jeffrey, R. F. C. Mantoura, and S. W. Wright, pp. 127-166, SCOR-UNESCO, Paris.

Kamatani, A. (1982), Dissolution rates of silica from diatoms decomposing at various temperatures, Mar. Biol., 68, 91-96.

Lampitt, R. S., B. J. Bett, K. Kiriakoulakis, E. E. Popova, O. Ragueneau, A. Vangriesheim, and G. A. Wolff (2001), Material supply to the abyssal seafloor in the northeast Atlantic, Prog. Oceanogr., 50, 27-63.

Leblanc, K., A. Leynaert, I. C. Fernandez, P. Rimmelin, T. Moutin, P. Raimbault, J. Ras, and B. Quéguiner (2005), A seasonal study of diatom dynamics in the North Atlantic during the POMME experiment (2001): Evidence for Si limitation of the spring bloom, J. Geophys. Res., doi:10.1029/2004JC002621, in press.

Lochte, K., H. W. Ducklow, M. J. R. Fasham, and C. Stienens (1993), Plankton succession and carbon cycling at $47^{\circ} \mathrm{N} 20^{\circ} \mathrm{W}$ during the JGOFS North Atlantic Bloom Experiment, Deep Sea Res., Part II, 40, 91-114. Longhurst, A. (1995), Seasonal cycles of pelagic production and consumption, Prog. Oceanogr., 36, 77-167.

Longhurst, A., S. Sathyendranath, T. Platt, and C. Caverhill (1995), An estimate of global primary production in the ocean from satellite radiometer data, J. Plankton Res., 17, 1245-1271.

Maixandeau, A., et al. (2005), Microbial community production, respiration, and structure of the microbial food web of an ecosystem in the northeastern Atlantic Ocean, J. Geophys. Res., doi:10.1029/2004JC002694, in press.

McCartney, M. S., and L. D. Talley (1982), The subpolar mode water of the North Atlantic Ocean, J. Phys. Oceanogr., 12, 1169-1188.

Mémery, L., G. Reverdin, J. Paillet, and A. Oschlies (2005), Introduction to the POMME special section: Thermocline ventilation and biogeochemical tracer distribution in the northeast Atlantic Ocean and impact of mesoscale dynamics, J. Geophys. Res., doi:10.1029/2005JC002976, in press.

Mortlock, R. A., and P. N. Froelich (1989), A simple method for the rapid determination of biogenic opal in pelagic marine sediments, Deep Sea Res., Part A, 36, 1415-1426.

Nelson, D. M., W. O. J. Smith, R. D. Muench, L. I. Gordon, C. W. Sullivan, and D. M. Husby (1989), Particulate matter and nutrient distributions in the ice-edge zone of the Weddell Sea: Relationship to hydrography during late summer, Deep Sea Res., Part I, 36, 191-209.

Nelson, D. M., P. Tréguer, M. A. Brzezinski, A. Leynaert, and B. Quéguiner (1995), Production and dissolution of biogenic silica in the ocean: Revised global estimates, comparison with regional data and relationship to biogenic sedimentation, Global Biogeochem. Cycles, 9, $359-372$. 
Nelson, D. M., et al. (2002), Vertical budgets for organic carbon and biogenic silica in the Pacific sector of the Southern Ocean, 1996-1998, Deep Sea Res., Part II, 49, 1645-1674.

Newton, P. P., R. S. Lampitt, T. D. Jickells, P. King, and C. Boutle (1994) Temporal and spatial variability of biogenic particle fluxes during the JGOFS northeast Atlantic process studies at $47^{\circ} \mathrm{N}, 20^{\circ} \mathrm{W}$, Deep Sea Res., Part I, 41, 1617-1642.

Paasche, E. (1973), Silicon and the ecology of marine plankton diatoms I. Thalassiosira pseudonana (Cyclotella nana) grown in a chemostat with silicate as the limiting nutrient, Mar. Biol., 19, 117-126.

Paillet, J., and M. Arhan (1996), Shallow pycnoclines and mode water subduction in the eastern North Atlantic, J. Phys. Oceanogr., 26, 96-114

Pesant, S., L. Legendre, M. Gosselin, E. Bauerfeind, and G. Budéus (2002)

Wind-triggered events of phytoplankton downward flux in the Northeast Water Polynya, J. Mar. Syst., 31, 261-278.

Ragueneau, O., N. Dittert, P. Pondaven, P. Tréguer, and L. Corrin (2002), $\mathrm{Si} / \mathrm{C}$ decoupling in the world ocean: Is the Southern Ocean different? Deep Sea Res., Part II, 49, 3127-3154.

Reverdin, G., M. Assenbaum, and L. Prieur (2005), Eastern North Atlantic Mode Waters during POMME (September 2000-2001), J. Geophys. Res., doi:10.1029/2004JC002613, in press.

Rios, A. P., T. R. Anderson, and P. P. Pérez (1995), The carbonic system distribution and fluxes in the NE Atlantic during spring 1991, Prog. Oceanogr., 35, 295-314.

Romero, O. E., G. Fisher, C. B. Lange, and G. Wefer (2000), Siliceous phytoplankton of the western equatorial Atlantic: Sediment traps and surface sediments, Deep Sea Res., Part II, 47, 1939-1959.

Sarmiento, J. L., R. Murnane, and C. Le Quéré (1995), Air-sea $\mathrm{CO}_{2}$ transfer and the carbon budget of the North Atlantic, Philos. Trans. R. Soc. London, Ser. B, 348, 211-219.

Scharek, R., M. Latasa, D. M. Karl, and R. R. Bidigare (1999), Temporal variations in diatom abundance and downward vertical flux in the oligotrophic North Pacific gyre, Deep Sea Res., Part I, 46, 1051-1075.

Scholten, J. C., J. Fietzke, S. Vogler, M. M. Rutgers van der Loeff, A. Mangini, W. Koeve, J. Waniek, P. Stoffers, A. Antia, and J. Kuss (2001), Trapping efficiencies of sediment traps from the deep eastern North Atlantic: The ${ }^{230}$ Th calibration, Deep Sea Res., Part II, 48, $2383-2408$.

Smetacek, V. S. (1985), Role of sinking in diatom life-history cycles: Ecological, evolutionary and geological significance, Mar. Biol., 84, $239-251$.
Stramska, M., T. D. Dickey, A. Plueddemann, R. Weller, C. Langdon, and J. Marra (1995), Bio-optical variability associated with phytoplankton dynamics in the North Atlantic Ocean during spring and summer of 1991, J. Geophys. Res., 100, 6621-6632.

Strickland, J. D. H., and T. R. Parsons (1972), A Practical Handbook of Seawater Analysis, 2nd ed., Rep. 167, 310 pp., Fish. Res. Board of Can., Ottawa.

Takahashi, T., T. T. Takahashi, and S. C. Sutherland (1995), An assessment of the role of the North Atlantic as a $\mathrm{CO}_{2}$ sink, Philos. Trans. R. Soc. London, Ser. B, 348, 143-152.

Usbeck, R., R. Schlitzer, G. Fischer, and G. Wefer (2003), Particle fluxes in the ocean: Comparison of sediment trap data with results from inverse modelling, J. Mar. Syst., 39, 167-183.

Wefer, G., and G. Fisher (1993), Seasonal patterns of vertical particle flux in equatorial and coastal upwelling areas of the eastern Atlantic, Deep Sea Res., Part I, 40, 1613-1645.

Westbroek, P., et al. (1993), A model system approach to biological climate forcing: The example of Emiliana huxleyi, Global Planet. Change, 8 , $27-46$.

Wroblewski, J. S., J. L. Sarmiento, and G. R. Flierl (1988), An ocean-basinscale model of plankton dynamics in the North Atlantic: 1. Solutions for the climatological oceanographic conditions in May, Global Biogeochem. Cycles, 2, 199-218

Yu, E. F., R. Francois, M. P. Bacon, S. Honjo, A. P. Fleer, S. J. Manganini, M. M. Rutgers van der Loeff, and V. Ittekot (2001), Trapping efficiency of bottom-tethered sediment traps estimated from the intercepted fluxes of ${ }^{230} \mathrm{Th}$ and ${ }^{231} \mathrm{~Pa}$, Deep Sea Res., Part I, 48, 865-889.

C. Guieu and N. Leblond, Laboratoire d'Océanographie de Villefranche, Université Pierre et Marie Curie, B.P. 08, F-06238 Villefranche-sur-mer, France. (guieu@obs-vlfr.fr; leblond@obs-vlfr.fr)

J. Mosseri, B. Quéguiner, and P. Rimmelin, Laboratoire d'Océanographie et de Biogéochimie, UMR 6535, Centre National de Recherche Scientifique/Université de la Méditerranée, OSU/Centre d'Océanologie de Marseille, Parc Scientifique et Technologique de Luminy, Case 901, F-13288 Marseille Cedex 09, France. (mosseri@com.univ-mrs.fr; queguiner@com.univ-mrs.fr; rimmelin@com.univ-mrs.fr) 